UNITED STATES DEPARTMENT OF THE INTERIOR

U.S. GEOLOGICAL SURVEY

\title{
Reconnaissance Geochemical Assessment of Metallic Mineral Resource Potential \\ South Egan Range Wilderness Study Area (NV 040-168), White Pine, Lincoln, and Nye Counties, Nevada
}

By

E. Lanier Rowan, Albert H. Hofstra, and Gordon W. Day

Open-File Report 84-782

1984

This report is preliminary and has not been reviewed for conformity with U.S. Geological Survey editorial standards. Any use of trade names is for descriptive purposes only and does not imply endorsement by the U. S. Geological Survey. 


\section{CONTENTS}

Page

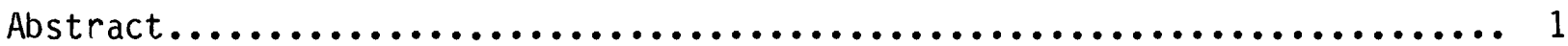

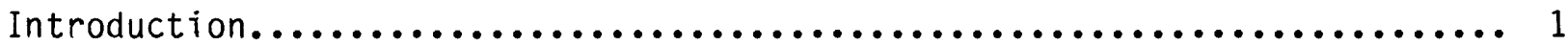

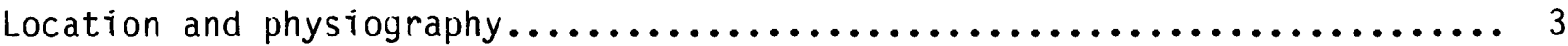

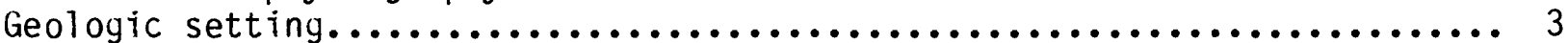

known metallic mineral resources.............................. 6

Geochemistry

Introduction...................................... 8

Sampling design....................................... 8

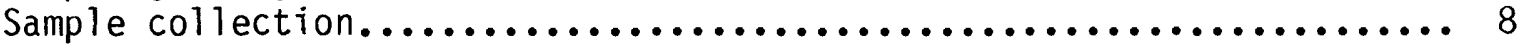

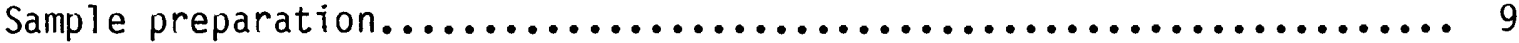

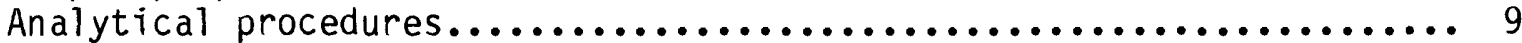

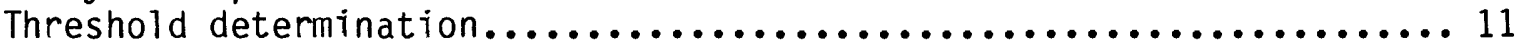

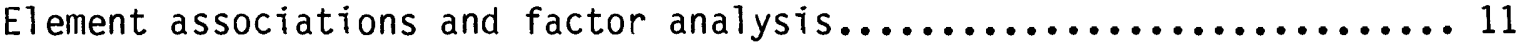

Interpretation of geochemical anomalies

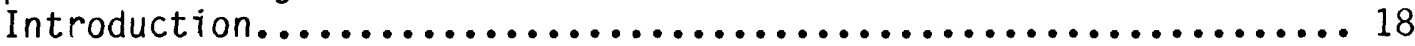

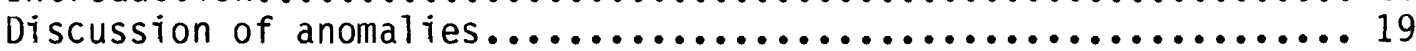

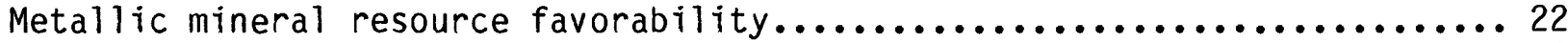

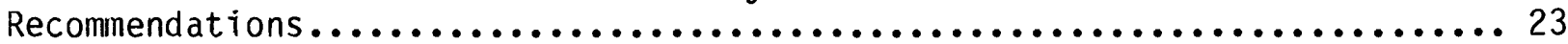

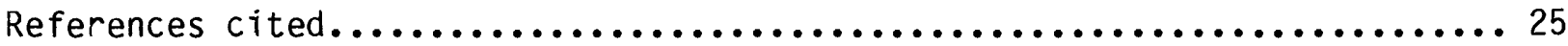

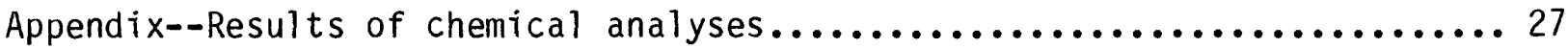

\section{TABLES}

Table 1. Resource potential classification scheme.................. 4

2. Elements associated with different deposit types............. 7

3a. Lower detection limits for sediment, heavy-mineral concentrate, and rock analyses................ 10

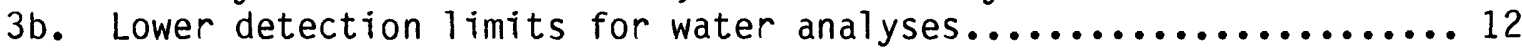

4. Threshold values and average elemental abundances...............13

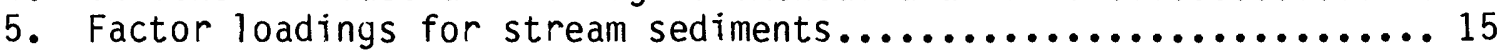

6. Factor loadings for heavy-mineral concentrates............... 16

7. Factor loadings for spring and well waters .....................

\section{APPENDICES}

Table A-1. Spectrographic and atomic absorption analyses of stream sediment samples................................. 28

A-2. Spectrographic and atomic absorption analyses of heavymineral (panned) concentrate samples....................43

A-3. Spectrographic and atomic absorption analyses of spring

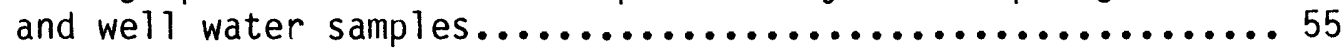

A-4. Spectrographic and atomic absorption analyses of

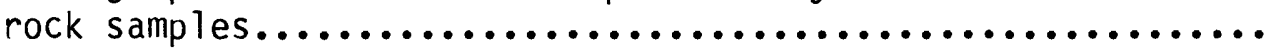




\section{FIGURES}

Figure 1. Study area location map............................. 2

2. Geochemical sample sites South Egan Range Wilderness

Study Area.......................................... 5

3. Metallic Mineral Resource Favorability Map.................. 24

PLATES

Plate 1. Geochemical Anomalies for stream sediment............... In pocket

2. Geochemical Anomalies for heavy-mineral concentrates....... In pocket

3. Geochemical Anomalies for spring water and rock samples... In pocket 


\section{ABSTRACT}

A reconnaissance geochemical study of the South Egan Range Wilderness Study Area (WSA) NV 040-168 was undertaken in 1983 as part of an assessment of the suitability of Bureau of Land Management administered land for preservation as wilderness. This study is intended to supplement earlier work by locating areas with metallic mineral resource potential not previously identified, and by classifying the study area according to metallic mineral resource favorability. Anomalous regions were defined primarily on the basis of chemical analyses of stream-sediment samples collected systematically throughout the WSA; rock and groundwater samples provided additional information. Emission spectrography and atomic absorption spectrophotometry were the primary methods of analysis.

In the northern part of the South Egan Range WSA two regions of known mineralization were identified, and accordingly, were classified 4D (highest favorability and certainty) for resource favorability. One region was classified $3 C$ (moderate favorability and certainty) on the basis of rock samples containing anomalous concentrations of $\mathrm{Au}$, $\mathrm{Ag}$, and base metals, a heavy-mineral-concentrate sample containing anomalous silver, and a water sample with anomal ous $\mathrm{SO}_{4}{ }^{-2}, \mathrm{~Pb}, \mathrm{Zn}, \mathrm{Cu}$, and $\mathrm{Mn}$. The suite of anomalous elements present in this region is suggestive of a base metal vein-type deposit; however, base metal skarn, and $\mathrm{Cu}$ /Mo porphyry deposit types are also possible. Three regions classified $2 \mathrm{C}$ (low favorability, moderate certainty) contain numerous scattered, anomalous concentrations of elements (e.g. $\mathrm{Cu}, \mathrm{Pb}$, $\mathrm{Mn}, \mathrm{Ni}, \mathrm{Sn}$ ) believed to reflect the relatively high background levels of these elements in the formations being drained. It is possible, however, that hydrothermal enrichment has been superimposed on the anomaly pattern related to lithology, and the anomalies are due to a combination of both sources. Finally, areas of Quaternary alluvium contained no significant anomalies and were classified 1B (low favorability and certainty).

\section{INTRODUCTION}

The Federal Land Policy Management Act of 1976 specifies that lands administered by the Bureau of Land Management (BLM) must be reviewed for suitability for preservation as wilderness (Fisher and Juilliand, 1983). One aspect of the review process is the evaluation of the metallic mineral resource potential. A Geology-Energy-Minerals (GEM) report (Great Basin GEM Joint Venture, 1983), a survey of the existing literature, initiated the evaluation of the South Egan Range Wilderness Study Area (WSA), NV 040-168, White Pine, Lincoln, and Nye Counties, Nevada (fig. 1). Based on recommendations made in the GEM report, a reconnaissance geochemical survey was undertaken to locate areas of metallic mineral resource potential not previously identified by prospects, claims, or private exploration. The geochemical survey is the subject of this report, and in conjunction with the GEM report, will provide the BLM with the information needed to make an initial recommendation of suitability for wilderness designation (Fisher and Juilliand, 1983).

Anomalous regions were defined primarily on the basis of chemical analyses of both bulk sediment and heavy-mineral concentrates from streamsediment samples collected systematically throughout the WSA. Analyses of water samples collected from springs and wells, and of rock samples collected 


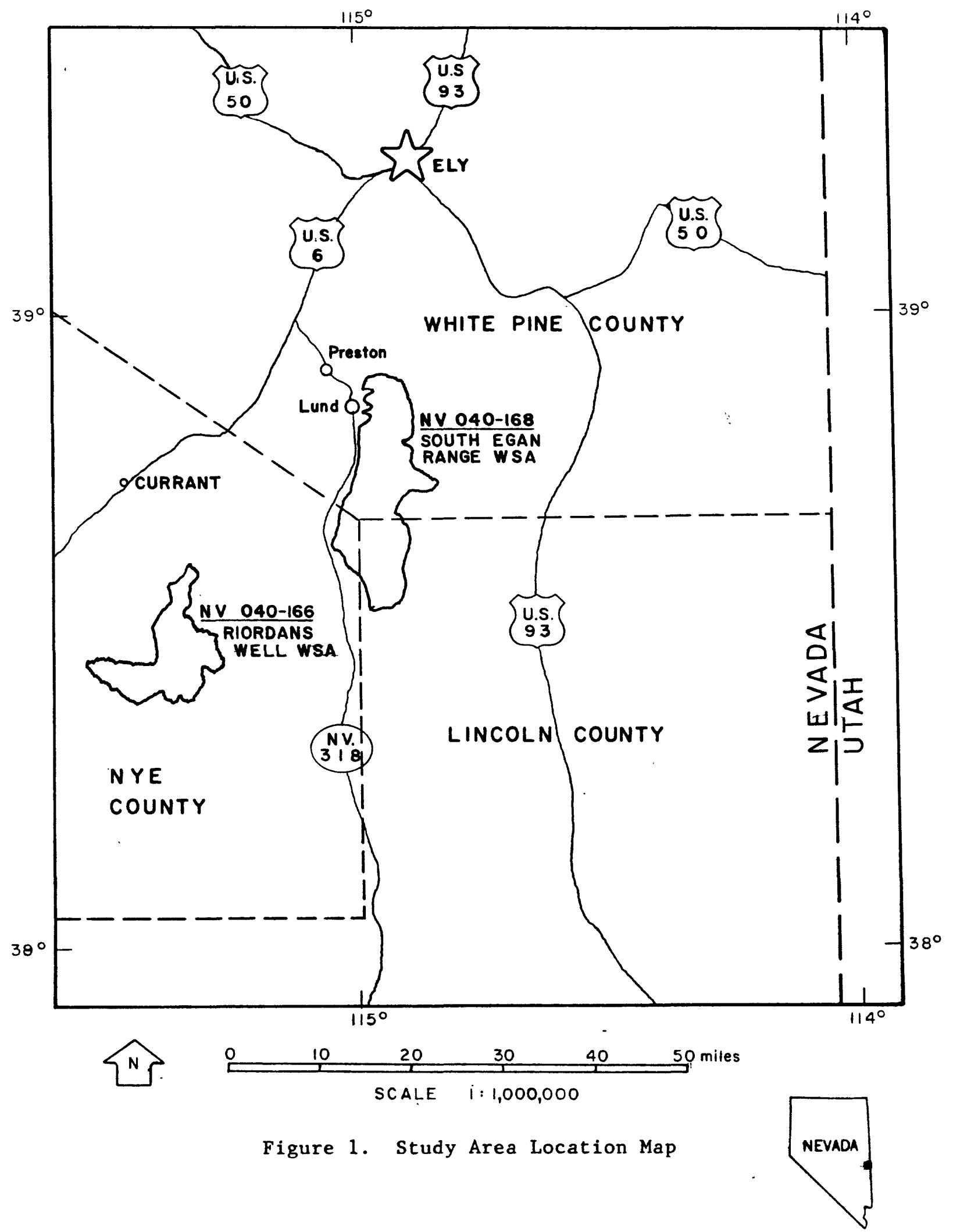


from outcrops with mineralized appearance, provided additional information. Regions within the South Egan Range WSA are ranked according to their resource potential using the classification scheme in table 1.

Stream sediment, spring and well water, and rock samples (fig. 2) were collected in June 1983 with the assistance of G. B. Allen. Chemical analyses of sediment and rock samples were performed by G. W. Day, and R. W. Leinz; water samples were analyzed by W. H. Ficklin. Manipulation of data and statistical analysis were performed by B. Chazin and R. J. Goldfarb.

\section{LOCATION AND PHYSIOGRAPHY}

The South Egan Range Wilderness Study Area (WSA) is located in eastcentral Nevada at the junction of White Pine, Lincoln, and Nye Counties, and covers approximately 151 square miles $\left(391 \mathrm{~km}^{2}\right)$. The northern boundary is about 25 miles south of Ely (fig. 1). Access to the study area is from highway 318 on the west and highway 93 on the east by dirt roads of varying quality. U.S. Geological Survey maps covering the area are the Sawmill Canyon, Brown Knoll, Parker Station, Haggerty Spring, Moorman Spring NE, Moorman Spring SE, Shingle Pass, and Lund quadrangles in the $1: 24,000$ scale topographic series.

The study area, a portion of the north-south trending Egan Range, is roughly 25 miles long and 8 miles wide. Relief is about 2,800 feet with a maximum elevation of 9,670 feet. The range is asymmetrical with a steep western slope above the White River Valley and a more gentle eastern slope descending into the Cave and Steptoe Valleys. The climate is arid to semiarid and most streams are intermittent.

\section{GEOLOGIC SETTING}

The South Egan Range Wilderness Study Area (WSA) is underlain primarily by Paleozoic sediments and Tertiary volcanic rocks. Deformation during the Late Cretaceous thrusting of the Sevier Orogeny and mid-Tertiary Basin and Range extensional faulting yielded a structurally complex terrane. Individual formations, structure, paleontology, and historical geology are discussed in detail in the Egan/Mt. Grafton GEM report (Great Basin GEM Joint Venture, 1983), and by Hose and Blake (1976), Tschanz and Pampeyan (1975), and Kellogg $(1964,1963)$. A more extensive reference list is provided by the GEM report.

The Paleozoic section is represented by formations from each period, Cambrian through Permian, and includes limestone, dolomite, sandstone, and shale. The following brief mention of the formations believed most important in contributing to yeochemical anomalies in the Paleozoic section has been condensed from the GEM report (Great Basin GEM Joint Venture, 1983). The Ordovician Pogonip Group consists primarily of platy, thin-bedded detrital limestone interbedded with flat-pebble conglomerate and shale. The Devonian formations include the Sevy and Simpson dolomites, and the Guilmette Formation which is an exceedingly dense, fine-grained, dark gray limestone. The cliffforming Mississippian Joana Limestone is a massive, medium gray unit. The overlying Chainman Shale is a dark gray to black shale interbedded with oliveyray, platy siltstone. The upper half of this formation contains beds of quartzite and quartzitic siltstone. The Pennsylvanian Ely Limestone is a medium gray coarsely crystalline, detrital limestone. These formations are 


\section{TABLE 1.--Resource potential classification scheme \\ (Fisher and Juilliand, 1983)}

I. Level of favorability

1. The geologic environment and the inferred geologic processes do not indicate favorability for accumulation of mineral resources.

2. The geologic environment and the inferred geologic processes indicate low favorability for accumulation of mineral resources.

3. The geologic environment, the inferred geologic processes and the reported mineral occurrences or valid geochemical/geophysical anomaly indicate moderate favorability for accumulation of mineral resources.

4. The geologic environment, the inferred geologic processes, the reported mineral occurrences, and/or valid geochemical/ geophysical anomaly, and the known mines or deposits indicate high favorability for accumulation of mineral resources.
II. Level of certainty

A. The available data are insufficient and/or cannot be considered as direct or indirect evidence to support or refute the possible existence of mineral resources within the respective area.

B. The available data provide indirect evidence to support or refute the possible existence of mineral resources.

C. The available data provide direct evidence, but are quantitatively minimal to support or refute the possible existence of mineral resources.

D. The available data provide abundant direct and indirect evidence to support or refute the possible existence of mineral resources. 


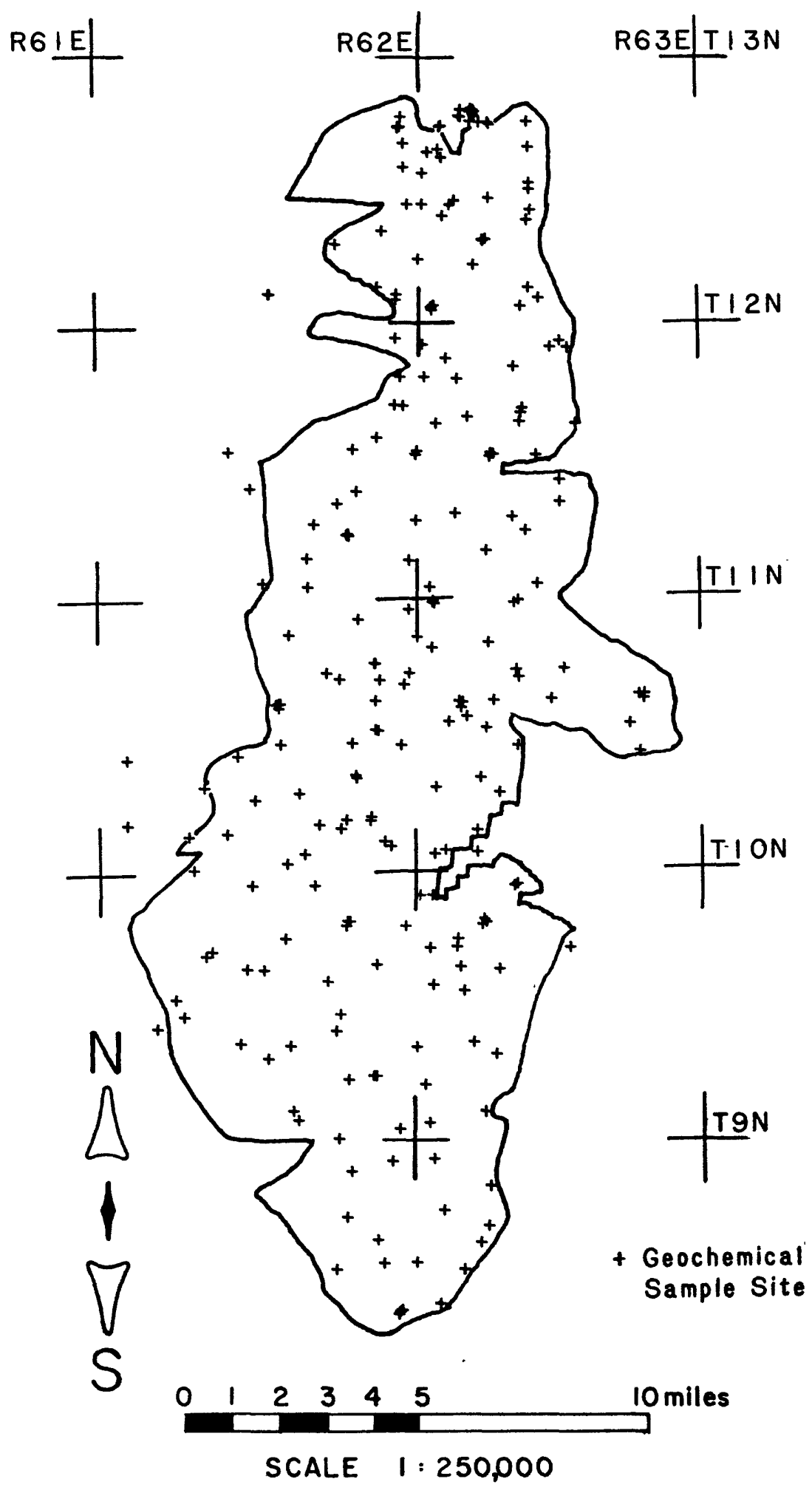

Figure 2. Geochemical Sample Sites--

South Egan Range Wilderness Study Area 
truncated on the west by a major listric(?)-normal fault developed during the Miocene east-west Basin and Range extension.

On the east side of the study area, the Paleozoic section is unconformably overlain by Tertiary non-marine sediments, which are themselves unconformably overlain by volcanic rocks. The volcanic rocks consist of a basal conglomerate which grades upwards into a sequence of flows and tuffs. Compositions are predominantly felsic although some intermediate to mafic units have been identified. These rocks are all disrupted by imbricate, lowangle faults developed probably in response to crustal extension of 01 igocene age (Gans and Miller, 1983). Other small outcrops of volcanic rocks are found on the western margin of the study area. Above the volcanic rocks along the eastern border of the range are poorly consolidated Pleistocene sandstone and conglomerate (Kellogg, H. E., 1964).

\section{KNOWN METALLIC MINERAL RESOURCES}

A compilation of known resources, prospects, claims, and leases, based on a survey of the literature and communication with individual companies and claim owners, is provided by the GEM report (Great Basin GEM Joint Venture, 1983). Description of deposit types expected in the area, strategic and critical mineral potential, and a discussion of mineral economics are also included in the GEM report. A summary of the known mineralization is presented here.

The Ellison mining district extends into the north end of the study area and in the 1930's and 1940's produced silver, copper, lead, zinc, and fluorite. Recent exploration by the U.S. Borax Company indicates potential for a molybdenum porphyry system at depth below the exposed fluorite, precious- and base-metal mineralization. Further study of the South Egan Ranye WSA was recommended in the GEM report (p.44) to define the southward extent of precious and base metal mineralization within the study area.

The volcanic rocks east of Lund at the western border of the study area have been drilled and found to contain currently subeconomic concentrations of disseminated gold. The GEM report concludes that there is some potential for an open-pit precious-metal and industrial minerals mine in this area.

Outside of the areas of known mineralization, outcrop in the study area was classified 2B (see table 1 for classification scheme) in the GEM report, i.e. low level of mineral resource favorability and a low level of certainty in this appraisal. Alluvium at the margins of the study area was classified $1 A$; $i . e$. no indication of favorability and no data on which to base an appraisal.

In the Ward district north of the WSA on the east side of the Egan Range, a mine currently under development will produce $\mathrm{Ag}$ and base metals from a skarn. Also to the north, about five miles west of Ely, is the Ruth Mine. Although no longer in production, it was once a major porphyry copper mine. Based on the mineral occurrences within and north of the study area, types of mineralization possibly occurring in the study area include: (1) epithermal precious-metal deposits as veins or disseminations; (2) base-metal veins; (3) argentiferous base-metal skarn deposits; and (4) Mo and/or Cu porphyry deposits. Major components and trace elements associated with these deposit types are listed in table 2 . 
TABLE 2.--Elements associated with different deposit types

(Rose, Hawkes, and Webb, 1979)

Type of deposit

Major components

Associated elements

\section{Hydrothermal deposits}

$\begin{array}{lll}\text { Porphyry Cu (Bingham) } & \mathrm{Cu}, \mathrm{S} & \begin{array}{c}\text { Mo, Au, Ag, Re, As, } \\ \mathrm{Pb}, \mathrm{Zn}, \mathrm{K}\end{array} \\ \begin{array}{ll}\text { Porphyry Mo (Climax) } \\ \text { Skarn-Cu (Yerington) }\end{array} & \mathrm{W}, \mathrm{Sn}, \mathrm{F}, \mathrm{Cu} \\ \text { Skarn-Pb (Hanover) } & \mathrm{Mo}, \mathrm{S} & \mathrm{Au}, \mathrm{Ag} \\ \text { Skarn-W-Mo-Sn (Bishop) } & \mathrm{Pb}, \mathrm{Zn}, \mathrm{S} & \mathrm{Cu}, \mathrm{Co} \\ \text { Base-metal veins } & \text { W, Mo, Sn } & \mathrm{F}, \mathrm{S}, \mathrm{Cu}, \mathrm{Be}, \mathrm{Bi} \\ \text { "Epithermal" precious metal } & \mathrm{Pb}, \mathrm{Zn}, \mathrm{Cu}, \mathrm{S} & \mathrm{Ag}, \mathrm{Au}, \mathrm{As}, \mathrm{Sb}, \mathrm{Mn}\end{array}$




\section{GEOCHEMISTRY}

\section{Introduction}

The purpose of this geochemical survey is to identify new regions of potentially significant mineralization within the South Egan Range Wilderness Study Area (WSA). For most of the study area no previous geochemical exploration results are known to exist. The results of the present study permit the areas classified $a s 2 B$ and $1 A$ in the GEM report (Great Basin GEM Joint Venture, 1983) to be further subdivided and reclassified with greater certainty.

A total of 183 bulk sediment samples, and 165 heavy-mineral-concentrate samples from stream sediments, 26 rock, and 52 water samples were collected and analyzed by semiquantitative direct-current arc emission spectrography and atomic absorption spectrophotometry. The results were entered into the U.S. Geological Survey's computerized archive, the Rock Analys is Storage System (RASS), and are presented in the appendix.

\section{Sampling Design}

Stream-sediment sample sites were chosen to provide representative coverage for a geochemical assessment of metallic mineral resource potential in the study area. The study area was divided into one-square-mile cells. In a given cell, if there was more than one appropriate site, one was chosen at random to represent the cell. Sites were generally located in first-order or small second-order streams draining areas of approximately $1 / 2$ to $3 / 4$ of a square mile. Differences in sediment geochemistry between sample sites should permit detection of geochemical halos surrounding major mineralized regions. However, the sample density of one site per square mile represents a compromise between sensitivity in detecting weaker, more dispersed geochemical halos, the probability of missing anomalies, and time and cost limitations. The Ellison district in the northern part of the area, and the subeconomic gold occurrence east of Lund were both clearly identified using the sampling methods of this study. It should be emphasized, however, that the sample density used only permits identification of geochemically anomalous regions where more detailed geochemical and geologic exploration should be focused.

\section{Sample Collection}

A sample of bulk sediment and a sample for heavy-mineral concentrate were each collected from 183 stream sediment sites. Due to insufficient quantity only 165 of the concentrate samples could be analyzed. At each site the bulk

sediment sample was composited from a 50-foot stretch of channel, using an aluminum scoop. All samples were passed through a 10-mesh (2-mm) sieve and placed into cloth sample bags. Larger samples (about 8 1bs), collected for analysis of the heavy minerals, were panned later and the heavy fraction saved.

Spring and well water samples were collected from 52 locations. At each site $400 \mathrm{ml}$ samples were stored in new, untreated plastic bottles, and $60 \mathrm{ml}$ samples were filtered through a 0.45 micrometer filter, acidified with reagent-grade concentrated nitric acid to $\mathrm{pH} 2$, and stored in acid-rinsed polyethylene bottles. Water temperature and $\mathrm{pH}$ were measured at each site. 
Rock samples were collected during the course of stream-sediment sampling from 26 outcrops, most of which showed some evidence of mineralization.

\section{Sample Preparation}

The samples of bulk sediment were passed through an 80 -mesh $(0.18-\mathrm{mm})$ stainless steel sieve and the fine fraction retained. This fraction includes clay, silt, fine sand, hydroxides, and organic matter. Previous work has shown that this size fraction has a high capacity for metal ion adsorption and that secondary minerals of ore deposits, particularly iron and manganese oxides, tend to be friable and break down to this size. After sieving, the sediment was split, one fraction saved, and the other submitted for spectrographic and atomic absorption analysis.

The heavy-mineral (panned) concentrates were passed through a 35-mesh $(0.5-\mathrm{mm})$ stainless steel sieve, and separated in bromoform (specific gravity 2.8) to remove any remaining light minerals (quartz, feldspar, etc.). The heavy minerals were separated into three fractions using a large electromagnet. The most magnetic material, largely magnetite, was discarded; the second fraction, largely ferromagnesian silicates and iron oxides, was stored for possible future analysis. The third and least magnetic fraction contained minerals such as zircon, sphene, rutile, sulfides, sulfates, carbonates, and oxides. When sufficient quantity of this fraction remained, it was divided using a Jones splitter. One split was hand ground for spectrographic analysis, and the other was stored.

Rock samples were crushed and then powdered between ceramic plates to less than $0.15 \mathrm{~mm}$. Water samples required no preparation beyond that done in the collection process.

\section{Analytical Procedures}

Emission spectrography (Grimes and Marranzino, 1968) was used to analyze all bulk sediment samples, heavy-mineral concentrates, and rock samples for 31 elements. The lower limit of detection for each element is given in table $3 a$. In general the precision is within one reporting value of the actual value $83 \%$ of the time, and within two intervals approximately $96 \%$ of the time (Motooka and Grimes, 1976).

The semiquantitative spectrographic analyses are reported as six-step geometric midpoints $(\ldots, 1,1.5,2,3,5,7,10,15, \ldots)$ of increasing geometric intervals $(\ldots, 0.83-1.2,1.2-1.8,1.8-2.6,2.6-3.8,3.8-5.6,5.6-$ $8.3,8.3-12,12-18, \ldots$.$) . These intervals represent logarithmic class widths$ of 0.16667 . The line density on the spectrographic plate is approximately proportional to the $\log$ of the amount of the element present. Consequentiy, the expected error in reading line densities is logarithmically related to the element concentration. Geometric classes are advantageous because the error variance is somewhat proportional to the concentration of the element detected (Miesch, 1976).

Arsenic, antimony, and silver are potentially important pathfinders for precious-metal mineralization known to occur in the geologic setting of the study area. Due to their relatively low natural concentrations and their relatively high spectrographic lower detection limits (table $3 a$ ), they are 
TABLE 3a.--Lower detection limits for sediment, heavy-mineral concentrate, and rock analyses

\begin{tabular}{ccc}
\hline Element & Method $\begin{array}{c}\text { Lower detection limit } \\
\text { for sediments (ppm) } \\
\text { and rock }\end{array}$ & $\begin{array}{c}\text { Lower detection limit } \\
\text { for heavy-mineral } \\
\text { concentrates (ppm) }\end{array}$
\end{tabular}

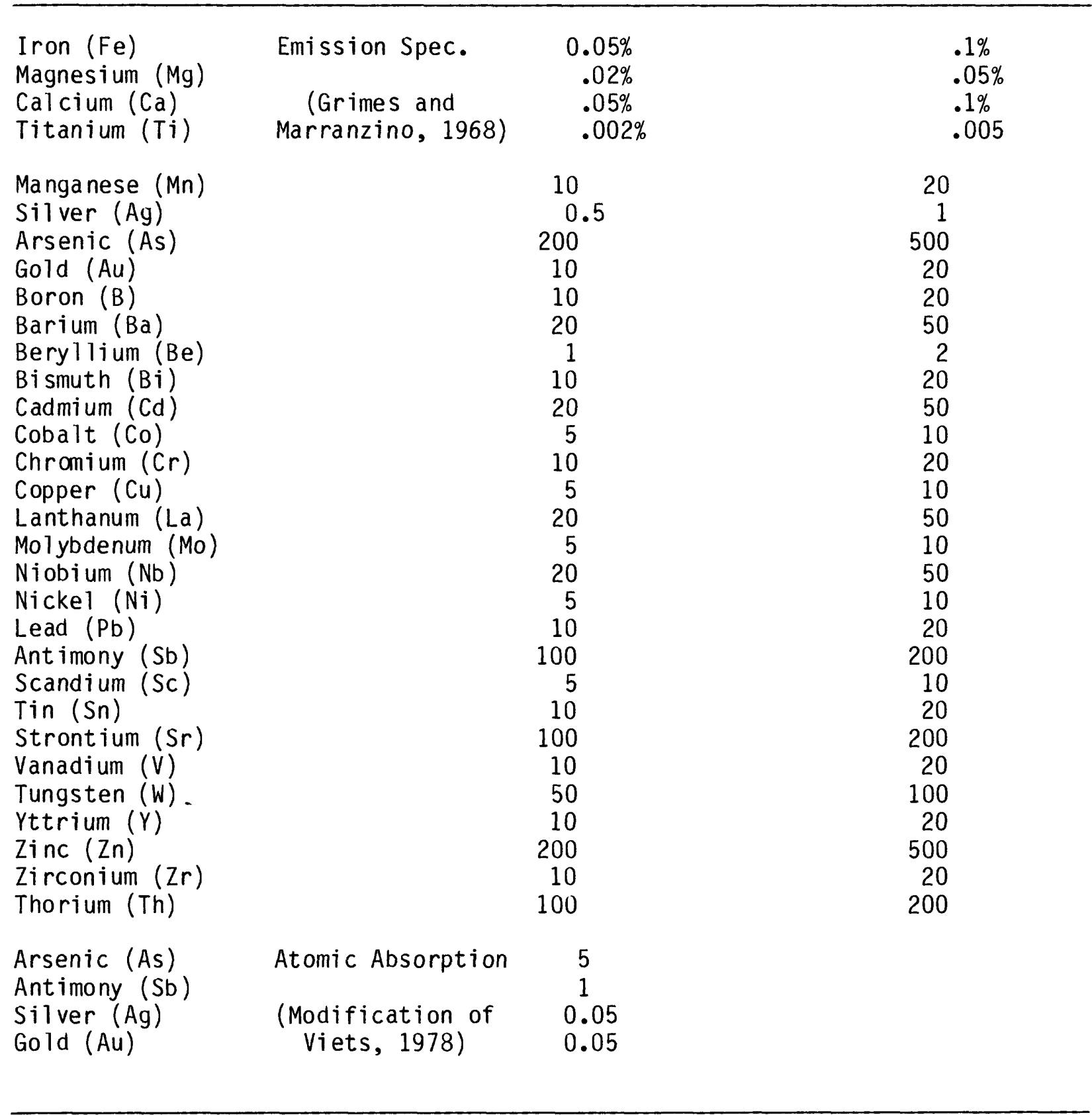


rarely detected in spectrographic analysis. Therefore atomic absorption analysis (Modification of Viets, 1978) of the bulk sediment samples was used for As, Sb, and Ag (table 3a).

Rock samples were analyzed spectrographically for 31 elements, and by atomic absorption for Au (Thompson and others, 1968) as well as As, Sb, and Ag (table 3a). Analyses performed on water samples are listed in table $3 b$. The results of chemical analysis of bulk sediment, heavy-mineral concentrate, rock, and water samples are listed in the appendix.

\section{Threshold determination}

The thresholds for element concentrations in the stream sediments are defined as the upper limit of background values. Values higher than threshold are considered anomalous and possibly related to mineralization. For the purpose of threshold determinations and statistical interpretation, the geochemical data for the Riordan's Well WSA (Hofstra and others, 1984) was combined with that of the South Egan Range WSA because the geology and types of mineralization are similar in both areas, and the statistics are generally more meaningful for a large data base.

Threshold values for each element were determined using cumulative frequency tables and percent frequency histograms, supplied by the STATPAC program A470 (VanTrump and Miesch, 1977), which provide a quick method for visual representation of the data. Modes can be easily recognized, and the frequency distribution of the data is apparent. Thresholds for el ements with normal distributions were placed at breaks in the frequency distribution of the data, if present, generally between the 95 th and 99 th percentiles (table 4). When multimodal distributions were identified, the threshold was placed at the point between the population thought to represent unmineralized lithologies, and the remaining values thought to represent mineralized rock.

A total of only 34 rock samples were obtained from both study areas, and because many of these were collected from mine dumps, the determinations of threshold values for rocks were based upon: (1) comparison of the data with average background abundances of the elements in different rock types (table 4); and (2) published surveys of known mineralized areas.

\section{Element associations and factor analysis}

Because certain groups of elements respond similarly to a given set of environmental conditions, associations of different elements may serve to identify more clearly the geochemical variations in the geological

environment. Associations of some elements may be related to rock type, while others may be related to a particular type of mineralization (see table 2 ).

Although data for a large number of chemical elements was acquired, geochemical associations permit the simplification of this data set into a smaller set of new variables, each consisting of a suite of elements. Factor analysis is a mathematical technique for deriving these new variables. R-mode factor analysis (VanTrump and Miesch, 1976; Davis, 1973) was used to define the geochemical associations in the sediment, concentrate, and water data bases. This type of factor analysis collects the experimental variables (elements) that tend to behave similarly into groups termed factors. Because 
TABLE 3b.--Lower detection limits for water analyses

\begin{tabular}{|c|c|c|c|}
\hline $\begin{array}{l}\text { Element or } \\
\text { constituent } \\
\text { determined }\end{array}$ & Method & $\begin{array}{l}\text { ection limit } \\
(\mathrm{ppb})\end{array}$ & Reference \\
\hline $\mathrm{Ag}$ & GFAA & .2 & Perkin-Elmer, 1977 \\
\hline As & GFAA & 1 & Aruscavage, 1977 \\
\hline $\mathrm{Li}$ & FAA & 10 & Perkin-Elmer, 1976 \\
\hline $\mathrm{Ca}$ & FAA & 100 & Perkin-Elmer, 1976 \\
\hline $\mathrm{Cu}$ & GFAA & 1 & Perkin-Elmer, 1977 \\
\hline $\mathrm{Fe}$ & GFAA & 1 & Perkin-E1mer, 1977 \\
\hline $\mathrm{Mn}$ & GFAA & 1 & Perkin-Elmer, 1977 \\
\hline K & FAA & 100 & Perkin-Elmer, 1976 \\
\hline Mg & FAA & 100 & Perkin-Elmer, 1976 \\
\hline Mo & GFAA & 1 & Perkin-Elmer, 1977 \\
\hline $\mathrm{Na}$ & FAA & 100 & Perkin-Elmer, 1976 \\
\hline $\mathrm{Pb}$ & GFAA & 1 & Perkin-Elmer, 1977 \\
\hline $\mathrm{Sb}$ & GFAA & 1 & Perkin-E1mer, 1977 \\
\hline $\mathrm{Zn}$ & GFAA & .5 & Perkin-Elmer, 1977 \\
\hline $\mathrm{SO}_{4}$ & Ion Chromatography & 100 & Fishman and Pyen, 1979 \\
\hline Alkalinity ${ }^{1}$ & Grans Plot, Titration & 1000 & Orion Research, 1973 \\
\hline $\mathrm{F}^{-}$ & Ion Chromatography & 10 & Fishman and Pyen, 1979 \\
\hline $\mathrm{Cl}^{-}$ & Ion Chromatography & 50 & Fishman and Pyen, 1979 \\
\hline Sp. Cond. & Specific Conductivity Bridge & -- & $\begin{array}{l}\text { Skougstad and others, } \\
1979\end{array}$ \\
\hline
\end{tabular}

GFAA Graphite furnace atomic absorption (Perkin-Elmer Corporation, 1977)

FAA Flame atomic absorption

1 As bicarbonate 


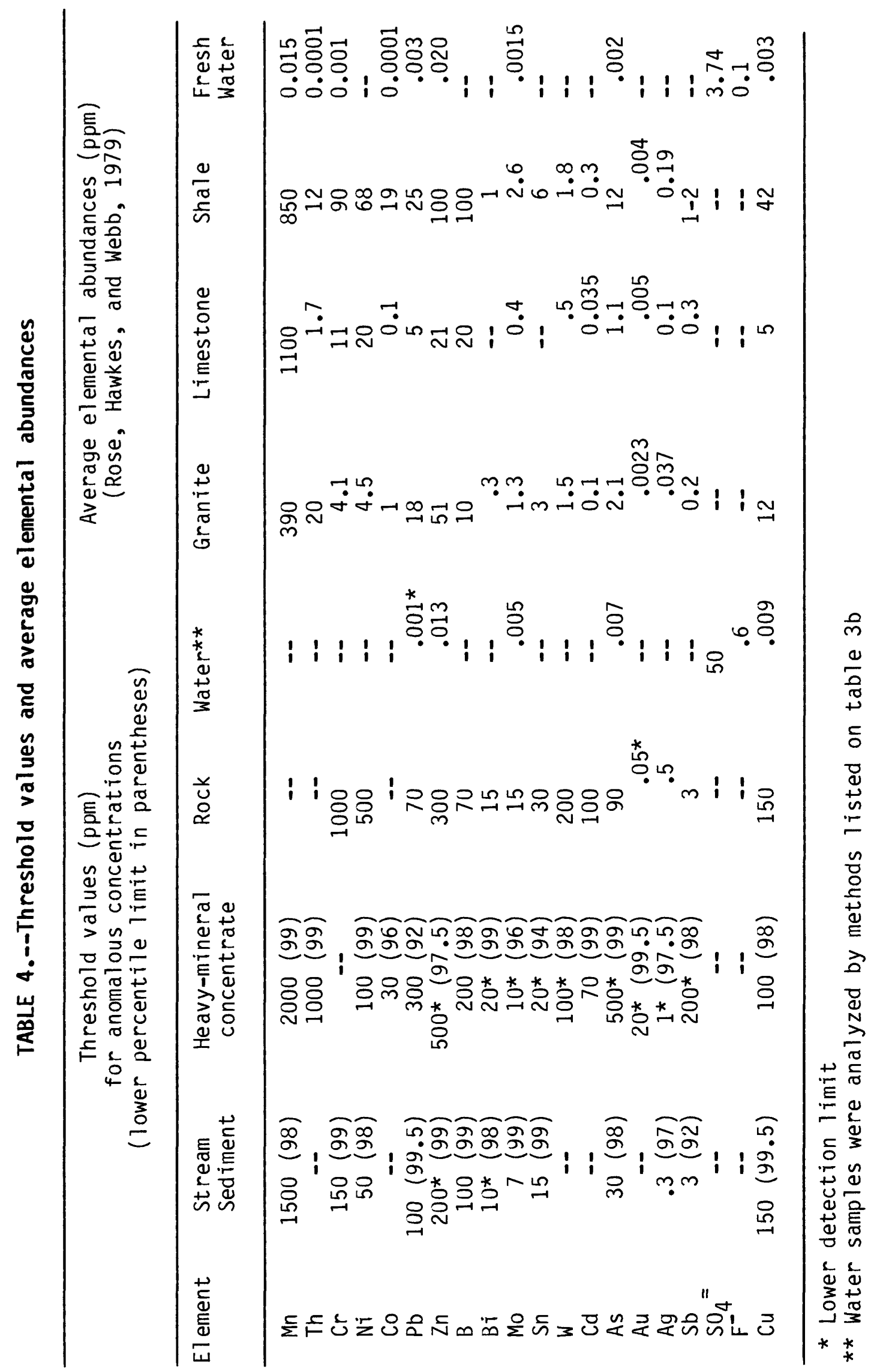


specific types of mineral deposits frequently contain a characteristic geochemical signature composed of a distinct suite of trace elements, factors may be useful in defining deposit types. In this study factor analysis did not directly affect the choice of boundaries of anomalous areas; however, it helped in choosing which elements to plot and in recognizing areas of lithologic control over geochemical anomalies.

The suite of elements that makes up a factor is determined through interpretation of the factor loadings which depict the influence of each factor on a variable (i.e, element), and may be interpreted similarly to correlation coefficients. In other words, a high positive or negative loading denotes, respectively, a positive or negative geochemical correlation between the element and the factor. Related to the loadings are the factor scores, which measure the magnitude of the factor's effect on each individual sample.

Tables 5, 6, and 7 show the factor loadings for the factors determined to be statistically significant (eigenvalues greater than one) within the sediment, concentrate, and water data bases, respectively.

The first two factors in stream sediments are related to lithology. Most of the elements in factor 1 (Y, Ti, V, Mn, Sc, Zr, Fe, Sr, Ba, La, Co, Be) are associated with felsic and alkalic igneous rocks (Rose, Hawkes, and Webb, 1979) and elements in factor 2 ( $\mathrm{Ca}, \mathrm{Mg}, \mathrm{Pb}$ ) are indicative of carbonates (table 5). The elements for these two factors were not plotted on the enclosed geochemical maps because the interest here is in metallic mineral deposits. Suites of elements in factors 3,4 , and 5 are less obviously attributable to discrete lithologies, and represent mixes of both mineralized and unmineralized sources. Factor 3 defines an element association whose most important constituents are $\mathrm{Ni}, \mathrm{Cu}$, and $\mathrm{As}$; similarly, the important constituents of factor 4 are $\mathrm{Cr}, \mathrm{Ni}, \mathrm{Ag}, \mathrm{B}$, and for factor $5, \mathrm{Zn}$. When factors are referred to throughout the text, their important constituents are 1 isted in parentheses. Anomalous concentrations of the important constituents of factors 3,4 , and 5 , as well as ore-related elements not included in the factor analysis, such as $\mathrm{Bi}$, Mo, Sb, and Sn, are plotted on plate 1.

The element associations in heavy-mineral concentrates defined by factors 1-5 are probably related to lithologic controls (table 6). Factor 6 , however, shows a strong loading with $\mathrm{Zn}$, and weaker $\mathrm{Pb}, \mathrm{Cu}$, and $\mathrm{Co}$ loadings defining a suite of elements often associated with metaliic mineralization. Plate 2 shows samples enriched in these elements and/or other elements not included in the factor analysis but possibly related to mineralization, including Ag, As, $\mathrm{Au}, \mathrm{Bi}, \mathrm{Cd}, \mathrm{Mo}, \mathrm{Sb}, \mathrm{Sn}$, and $\mathrm{W}$.

In spring waters, factors 4 and 5 are the most likely to be representative of mineralization (table 7). Factor 4 has strong positive loadings for $\mathrm{Zn}$ and $\mathrm{Cu}$, while factor 5 has strong positive loadings for $\mathrm{F}^{-}$and $\mathrm{SO}_{4}{ }^{-2}$, and a slightly weaker loading for Mo. Sample sites with anomalous concentrations of these elements are plotted on plate 3 . Factor analysis was not applicable to the rock data due to the small number of samples. 
TABLE 5.--Factor loadings for stream sediments, $R$-mode factor analysis, VARIMAX factor rotation

\begin{tabular}{|c|c|c|c|c|c|}
\hline Variable & Factor 1 & Factor 2 & Factor 3 & Factor 4 & Factor 5 \\
\hline $\mathrm{Fe} \%, \ldots . .$. & $\underline{0.8248}$ & -0.0677 & 0.0556 & 0.1276 & 0.3547 \\
\hline$M g \%, \ldots . .$. & -0.2446 & 0.8071 & -0.2142 & 0.0595 & 0.0113 \\
\hline Ca\%........ & -0.1554 & $\underline{0.7940}$ & 0.1538 & 0.0627 & -0.1712 \\
\hline Ti\%....... & $\underline{0.8676}$ & -0.1294 & 0.1736 & 0.0347 & 0.2004 \\
\hline$M n \ldots . . .$. & $\underline{0.8553}$ & 0.1885 & 0.1173 & 0.1991 & 0.1306 \\
\hline B......... & 0.4567 & 0.1754 & 0.2865 & $\underline{0.6395}$ & -0.2360 \\
\hline $\mathrm{Ba} . . . . .$. & $\underline{0.8025}$ & 0.2842 & -0.1936 & 0.2502 & -0.1228 \\
\hline Be........ & $\underline{0.5779}$ & 0.2851 & -0.2370 & 0.3654 & -0.3144 \\
\hline Co......... & 0.6862 & -0.2105 & 0.0950 & 0.3256 & 0.2852 \\
\hline Cr........ & 0.4760 & 0.2953 & 0.0263 & 0.6471 & 0.0700 \\
\hline $\mathrm{Cu} . . . . . .$. & 0.2421 & 0.1978 & 0.7136 & -0.2070 & 0.2576 \\
\hline La......... & $\underline{0.7978}$ & -0.1687 & -0.1625 & -0.1193 & -0.0152 \\
\hline Ni........ & 0.2057 & 0.0048 & $\underline{0.5653}$ & 0.6479 & -0.0863 \\
\hline $\mathrm{Pb}, \ldots \ldots \ldots$ & 0.3896 & $\underline{0.6863}$ & 0.0497 & 0.1239 & 0.0481 \\
\hline sc........ & 0.8505 & -0.0448 & 0.0010 & 0.2071 & 0.0751 \\
\hline sr........ & 0.8084 & 0.1332 & -0.0803 & 0.1201 & -0.1310 \\
\hline$v \ldots \ldots \ldots$ & $\underline{0.8565}$ & 0.0088 & 0.1375 & 0.2094 & 0.2805 \\
\hline$\gamma_{\ldots} . . . \ldots$. & 0.8682 & -0.0012 & 0.0362 & 0.3125 & 0.0352 \\
\hline Zn........ & 0.2269 & -0.0782 & 0.0021 & 0.0792 & $\underline{0.8739}$ \\
\hline Zr........ & $\underline{0.8277}$ & -0.0793 & 0.1296 & -0.0032 & 0.0412 \\
\hline As........ & -0.1810 & -0.1340 & $\underline{0.6855}$ & 0.0839 & -0.1061 \\
\hline Ag........ & 0.0220 & 0.0323 & -0.2257 & 0.7782 & 0.2275 \\
\hline $\begin{array}{l}\text { Percent of } \\
\text { total data } \\
\text { variance } \\
\text { explained } \\
(75.51 \%)\end{array}$ & $43.65 \%$ & $\underline{12.14 \%}$ & $8.05 \%$ & $6.26 \%$ & $5.41 \%$ \\
\hline $\begin{array}{l}\text { El ement } \\
\text { Assoc. }\end{array}$ & $\begin{array}{l}\text { Y, Ti, V, } \\
\text { Mn, Sc, } \\
\mathrm{Zr}, \mathrm{Fe}, \\
\text { Sr, Ba, } \\
\mathrm{La}, \mathrm{Co}, \mathrm{Be}\end{array}$ & $\underset{\mathrm{Pb}}{\mathrm{Mg}} \mathrm{Ca}$, & $\underset{\mathrm{Ni}}{\mathrm{Cu}}{ }^{\mathrm{As}}$ & $\begin{array}{l}\mathrm{Ag}, \mathrm{Ni}, \\
\mathrm{Cr}, \mathrm{B}\end{array}$ & Zn \\
\hline
\end{tabular}


TABLE 6.--Factor loadings for heavy-mineral concentrates $R$-Mode factor analysis, VARIMAX factor rotation

\begin{tabular}{|c|c|c|c|c|c|c|}
\hline Variable & Factor 1 & Factor 2 & Factor 3 & Factor 4 & Factor 5 & Factor 6 \\
\hline $\mathrm{Fe} \% . . . . .$. & 0.7776 & 0.2799 & -0.0051 & 0.2664 & 0.0775 & -0.0195 \\
\hline$M g \% . . . . .$. & -0.0634 & 0.1008 & -0.4296 & $\underline{0.7621}$ & -0.2479 & 0.0188 \\
\hline Ca\%........ & 0.2754 & -0.3404 & 0.1361 & $\underline{0.7416}$ & 0.1682 & -0.0120 \\
\hline Ti\%........ & $\underline{0.5040}$ & $\underline{0.7095}$ & 0.0800 & -0.0500 & -0.0014 & -0.0194 \\
\hline Mn........ & $\underline{0.7487}$ & 0.2832 & -0.1321 & -0.1383 & -0.1516 & 0.1202 \\
\hline B......... & $\underline{0.6242}$ & -0.1809 & 0.1172 & 0.0284 & 0.2943 & 0.2168 \\
\hline Ba........ & 0.1771 & 0.1099 & 0.0506 & 0.0514 & $\underline{0.8590}$ & 0.0424 \\
\hline Be........ & -0.1390 & 0.1449 & $\underline{0.7602}$ & 0.0343 & -0.1266 & 0.0690 \\
\hline Co........ & $\underline{0.6788}$ & 0.2325 & -0.1810 & -0.0868 & -0.1370 & $\underline{0.3046}$ \\
\hline Cr......... & $\underline{0.6583}$ & 0.0799 & 0.1735 & 0.3719 & 0.0645 & -0.1414 \\
\hline Cu......... & $\underline{0.7224}$ & 0.0065 & -0.0024 & 0.1066 & 0.1458 & 0.3005 \\
\hline La........ & 0.6177 & 0.3939 & 0.4304 & -0.0590 & 0.0557 & -0.2311 \\
\hline $\mathrm{Nb} . . . . .$. & 0.0972 & 0.6324 & 0.1713 & 0.2097 & -0.2897 & 0.1470 \\
\hline Ni........ & 0.7939 & -0.1010 & 0.0992 & 0.1177 & 0.1438 & -0.1017 \\
\hline $\mathrm{Pb} \ldots . . . .$. & 0.2859 & 0.1451 & 0.1608 & 0.4746 & 0.1011 & 0.4989 \\
\hline sc........ & 0.1709 & 0.7369 & 0.0573 & -0.1827 & 0.0894 & -0.1619 \\
\hline sr........ & 0.1432 & -0.1452 & $\underline{0.6451}$ & -0.1005 & 0.5073 & -0.0356 \\
\hline v......... & $\underline{0.7973}$ & 0.3779 & 0.0125 & 0.1072 & 0.1015 & -0.0354 \\
\hline Y.......... & 0.4738 & 0.4283 & $\underline{0.5303}$ & 0.0094 & 0.2432 & -0.2488 \\
\hline Zn........ & 0.0664 & -0.1334 & -0.0610 & -0.0356 & -0.0023 & 0.8049 \\
\hline Zr........ & -0.0240 & 0.6877 & -0.0776 & -0.0537 & 0.4741 & -0.0559 \\
\hline $\begin{array}{l}\text { Percent of } \\
\text { total data } \\
\text { variance } \\
\text { explained } \\
(70.76 \%)\end{array}$ & $31.47 \%$ & $12.16 \%$ & $10.11 \%$ & $6.52 \%$ & $5.28 \%$ & $\underline{5.22 \%}$ \\
\hline $\begin{array}{l}\text { Element } \\
\text { Assoc. }\end{array}$ & $\begin{array}{l}\text { V, } \mathrm{Ni}, \mathrm{Fe} \\
\mathrm{Mn}, \mathrm{Cu}, \mathrm{Co} \\
\mathrm{Cr}, \mathrm{B}, \mathrm{La}, \\
\mathrm{Ti}\end{array}$ & $\begin{array}{l}\mathrm{Sc}, \mathrm{Ti} \\
\mathrm{Zr}, \mathrm{Nb}\end{array}$ & Be, ${ }_{Y} S r$ & $\mathrm{Mg}, \mathrm{Ca}$ & $\mathrm{Ba}, \mathrm{Sr}$ & $\begin{array}{l}\mathrm{Zn},(\mathrm{Pb}), \\
(\mathrm{Co}),(\mathrm{Cu})\end{array}$ \\
\hline
\end{tabular}


TABLE 7.--Factor loadings for spring and well waters

R-Mode factor analysis, VARIMAX factor rotation

\begin{tabular}{|c|c|c|c|c|c|}
\hline Variable & Factor 1 & Factor 2 & Factor 3 & Factor 4 & Factor 5 \\
\hline As........ & 0.5383 & -0.0045 & 0.2213 & -0.5029 & -0.3251 \\
\hline Li....... & 0.5837 & 0.1865 & 0.2243 & 0.1954 & 0.2517 \\
\hline $\mathrm{Ca} \ldots . . .$. & 0.1767 & -0.0303 & 0.8920 & -0.1112 & 0.0439 \\
\hline $\mathrm{Cu} . . . .$. & -0.0580 & 0.4471 & 0.1098 & 0.7045 & -0.0525 \\
\hline Fe....... & -0.0310 & 0.8272 & 0.0679 & 0.1968 & -0.1397 \\
\hline Mn....... & -0.0807 & 0.8539 & -0.1681 & 0.106 & 0.0007 \\
\hline$k \ldots \ldots \ldots$ & 0.7168 & 0.0262 & -0.0252 & -0.0177 & -0.0327 \\
\hline Mg....... & -0.0010 & -0.4300 & 0.5987 & 0.2872 & 0.3509 \\
\hline Mo....... & 0.5070 & 0.4523 & 0.0209 & -0.2429 & 0.4662 \\
\hline $\mathrm{Na} . . . . .$. & 0.8929 & -0.1641 & 0.0846 & -0.1204 & 0.1000 \\
\hline $\mathrm{Pb} \ldots \ldots$. & 0.0230 & 0.2898 & -0.3243 & 0.1299 & -0.5559 \\
\hline$Z n \ldots \ldots$. & 0.0068 & -0.0006 & -0.0687 & 0.9010 & 0.0960 \\
\hline $\mathrm{SO}_{4} \ldots \ldots$ & 0.6274 & -0.0400 & 0.3043 & -0.0633 & $\underline{0.5101}$ \\
\hline Alkalinity... & 0.1951 & -0.0915 & 0.9152 & -0.0354 & 0.0525 \\
\hline$F \ldots \ldots \ldots$ & 0.5415 & 0.0021 & 0.2524 & 0.0601 & 0.6317 \\
\hline C1........ & 0.8388 & -0.1236 & 0.2662 & -0.0215 & 0.0845 \\
\hline Sp. Cond.... & 0.3419 & -0.1308 & 0.8827 & 0.0151 & 0.2323 \\
\hline $\begin{array}{l}\text { Percent of } \\
\text { total data } \\
\text { variance } \\
\text { explained } \\
(72.92 \%)\end{array}$ & $33.49 \%$ & $14.05 \%$ & $12.39 \%$ & $7.27 \%$ & $5.72 \%$ \\
\hline $\begin{array}{l}\text { Element } \\
\text { As soc. }\end{array}$ & $\begin{array}{l}\mathrm{Na}, \mathrm{Cl}, \\
\mathrm{K}, \mathrm{SO}_{4}, \\
\mathrm{Li}, \mathrm{F}, \\
\mathrm{As}, \mathrm{Mo}\end{array}$ & $\mathrm{Mn}, \mathrm{Fe}$ & $\underset{\mathrm{Mg}}{\mathrm{Alk}, \mathrm{Ca},}$ & $\mathrm{Zn}, \mathrm{Cu}$, & $\begin{array}{l}\mathrm{F}, \mathrm{SO}_{4} \\
\mathrm{Mo}\end{array}$ \\
\hline
\end{tabular}




\section{Interpretation of geochemical anomalies}

\section{Introduct ion}

Under ideal conditions, the occurrence of anomalously high concentrations of an ore-related element, or a specific association of elements in a sample, may indicate that economic mineralization is present. Anomalies not related to mineralization may be caused by: (1) rock types with high background concentrations of ore-related elements; (2) concentration of normal background abundances of ore elements by coprecipitation with iron and manganese oxides and by adsorption by clays and organics; (3) contamination; (4) sampling or analytical errors; and (5) random statistical variation.

The absence of an anomaly does not necessarily mean that a mineral deposit does not exist. The deposit may occur too deep, or below an impervious layer that prevents transport of elements into the sample medium. In stream sediments and spring waters, dilution and/or immobilization of elements may cause samples collected in the vicinity of mineralization to show only sub-threshold values. Regions of interest are generally sites with anomalous concentrations of two or more ore metal elements and/or clusters of anomalous sites, particularly when reinforced by anomalies in different sample media, (e.g. bulk stream sediment, heavy-mineral concentrates, spring water, and rock).

The study area has been subdivided into zones defined by clusters or trends of geochemically anomalous sample sites. The anomalous zones referred to throughout the text, M1 through M5, are shown on plates 1-3 and figure 3 . Geologic coverage exists at a scale of $1: 62,000$ for the southern $2 / 3$ of the study area, south of $38^{\circ} 45^{\prime}$ (Kellogg, 1964), and at a scale of $1: 250,000$ for the northern portion (Hose and Blake, 1975). Thus the formations outcropping in individual drainage basins could be identified with fair confidence only in the southern part of the study area. The two areas of known mineralization, designated M1 and M2, were drawn with highly generalized boundaries because the detailed geology and/or higher density of geochemical sampling necessary for greater precision were not available. Areas M3a and M3b are defined on the basis of linear trends of distinct geochemical signature; the $1: 62,000$ scale geologic map, however, permitted more precise placement of the boundaries than would have been possible using only the geochemistry.

The geochemistry of the South Egan Range WSA may be compared with that of the Riordan's Well WSA, NV 040-166 (Hofstra and others, 1984). Since the same Paleozoic formations outcrop there, chemical analyses from Riordan's Well WSA were combined with those of the South Egan Range WSA to form a single data base. Although lithologically similar, the Riordan's Well WSA has only four samples with anomalous $\mathrm{Pb}$ in the heavy-mineral concentrates, while the Egan study area has scores of such samples. This marked contrast suggests possible differences in the recent (after Basin and Range extension) hydrothermal histories of the two areas. Regional variation in the primary $\mathrm{Pb}$ content of the carbonate sequences may also be a contributing factor. In general, geochemical anomalies in the South Egan Range WSA tend to be broadly distributed throughout the area rather than clustered as in the Riordan's Well WSA. 
It is distinctly possible that the same ore-forming processes that produced the Ellison district deposits have operated on other parts of the entire Paleozoic section resulting in widely dispersed, but geochemically detectable traces of mineralization throughout the Egan study area. Nevertheless, mineralization of a similar economic importance to the Ellison district is not indicated by the data. A shallow intrusion in the Ellison district and the presence of some Tertiary lava flows and tuffs within the area imply that the existence of additional shallow intrusions beneath the study area is not unlikely. The extensive fracturing and faulting present within the area would provide access for circulating hydrothermal fluids to most of the Paleozoic section. Since two essential ingredients of an oreforming system are a heat source (the Ellison district intrusion and/or additional undiscovered intrusions) and a fracture system, it is thus highly speculative, but plausible that widespread, low-level hydrothermal alteration has enriched large areas and produced a random pattern of scattered anomalies.

Local "pockets" of greater interest occur within the regional lithologically-controlled pattern of anomalies. These are generally clusters of sites of anomalous concentrations of two or more ore-metal elements reinforced by anomalies in a different medium (sediments, concentrates, rock, or water). Hydrothermal enrichment superimposed on the lithologic contribution would help explain the small regions of anomalous suites such as $\mathrm{Mo}-\mathrm{Cu}-\mathrm{Zn}-\mathrm{Pb}-( \pm \mathrm{Sn} \pm \mathrm{Cd} \pm \mathrm{Mn})$. Because many of these elements are commonly associated with Cu-Mo porphyry and base-metal vein systems, the strongest of these anomalies may merit more detailed geochemical sampling and geologic mapping.

\section{Discussion of anomalies}

Zones M1 and M2 have been classified 4D because they are known to contain mineral resources (fig. 3). The associations of anomalous metals in these two regions may help to identify similar types of mineralization in other parts of the study area. It should be noted that the terms "mineralization" and "resource" do not imply the existence of an ore deposit. They refer only to accumulations of ore minerals of subeconomic unspecified or unknown grade (Brobst and Pratt, 1973; McKelvey, 1972).

Ml includes the southern end of the Ellison district where veins were mined for precious and base metals, and a porphyritic intrusion with potential for molybdenum mineralization lies below the near-surface vein system. This region is best defined by anomalous elements in the heavy-rnineral concentrates, particularly lead. Of the 12 concentrate sites (duplicate sites not included) in this area, 9 have anomalous lead, 5 have anomalous $\mathrm{Cu}$ and $\mathrm{Zn}$, and 3 have anomalous $\mathrm{Sn}$, Mo, and Bi. In addition, high scores for factor 6 (see discussion of element associations) in which the most important constituents are $\mathrm{Co}, \mathrm{Cu}, \mathrm{Pb}$, and $\mathrm{Zn}$, appeared at 6 sites.

The bulk sediment samples showed 6 anomalous values at only 3 sites in M1. At 2 sites $\mathrm{Ag}$, As, and factor 3 (important constituents: $\mathrm{Cu}, \mathrm{As}, \mathrm{Ni}$ ) scores were anomalous; at one site B was anomalous. Rock samples generally showed elevated values for a large suite of elements: $\mathrm{Ag}, \mathrm{Bi}, \mathrm{Cd}, \mathrm{Cu}, \mathrm{Mo}, \mathrm{Sn}$, $\mathrm{W}, \mathrm{Pb}, \mathrm{Zn}, \mathrm{As}$, and $\mathrm{Sb}$. Four spring samples collected several miles east of $\mathrm{Ml}$ showed anomalous $\mathrm{Pb}$ and $\mathrm{Cu}$ concentrations. 
Elevated $\mathrm{Cu}$ and $\mathrm{Mn}$ in concentrates at three sites (E015, E132, and E025) south and southeast of Ml suggest a possible extension of the same ore-forming system. It is also possible, however, for background levels of $\mathrm{Cu}$ to be concentrated to anomalous levels through adsorption by $\mathrm{Mn}$ oxides. As mentioned earlier, the lack of detailed geology (i.e., the exact position of the Paleozoic-Tertiary boundary with respect to individual drainage basins) combined with the sample density of approximately one site per square mile, prevents the boundaries of areas M1 (and M2) from being drawn with greater precision.

Zone M2 is an area of known (subeconomic) disseminated $\mathrm{Au}$ and $\mathrm{Ag}$ mineralization. This occurrence is best delineated by enrichments of As in bulk sediments and $\mathrm{Zn}$ in the heavy-mineral concentrates. The presence of As is expected because of its strong association with gold. The anomalous $\mathrm{Zn}$ in the concentrates from the same sites was not expected, and together with the As, provides an element association potentially useful in interpreting similar anomalies. Spatially associated anomalous scores for factor 6 in concentrates ( $\mathrm{Co}, \mathrm{Cu}, \mathrm{Pb}, \mathrm{Zn}$ ) and for factor $3(\mathrm{Cu}, \mathrm{As}, \mathrm{Ni}$ ) in the sediments reinforce the single element anomalies. In addition, a rock sample (E117R) collected from the center of the area contained highly anomalous (580 ppm) As.

Regions M3a and M3D (plates 1,2, and 3) are adjacent northeast-trending anomalous belts. In general, sites in each belt drain basins within different geologic fomations because the belts are separated by a lithologically controlled asymmetric ridge. Streams within M3a generally flow northwest from the ridge or down stratigraphic section, while streams within M3b generally flow southeast from the ridge or up section. Sites within M3a drain primarily the Devonian Guilmette Formation with contributions from older units such as the Silurian Simpson and Sevy dolomites and the Ordovician Pogonip Group; sites in M3b drain primarily the Missippian Joana Limestone and younger units such as the Chainman Shale and the Pennsylvanian Ely Limestone. For purposes of discussion the boundaries of $M 3 a$ and M3b have been terminated to the south where a drainage divide no longer separates the two regions, or permits distinction of two separate geochemical trends. The anomalous element suites of regions M3a and M3b continue to appear to the south, but without topographic separation of basin systems draining different formations, the "signatures" of M3a and M3b overlap and blend together.

The principal differences between regions $M 3 a$ and $M 3 b$ are as follows. Region M3a is characterized by anomalous Mo in concentrates, while region M3b with one exception, has none. M3b is best defined by anomalous $\mathrm{Ni}$, B, and $\mathrm{Ag}$ $( \pm Z n, C u, P b$, and $M n)$ in sediments, very strongly reinforced by anomalous scores for factor $3(\mathrm{Cu}, \mathrm{As}, \mathrm{Ni})$ and factor $4(\mathrm{Cr}, \mathrm{Ni}, \mathrm{B}, \mathrm{Ag})$; region $\mathrm{M} 3 \mathrm{a}$, except for one occurrence of factor 3 , contains no anomalous sediment samples. The exceptions to these observations are in the zones where the distinctive signatures of the two belts overlap.

The $\mathrm{Ni}$ and $\mathrm{B}$ concentrations in the sediments do not significantly exceed the average abundances reported for these elements in shale (table 4). Although anomalous with respect to the rest of the study area, it appears that they merely represent relatively high background levels of these elements within the formations being drained rather than mineral potential. The anomalous Ag might be in part explained by enrichment through coprecipitation of background $\mathrm{Ag}$ concentrations with $\mathrm{Mn}$ and $\mathrm{Fe}$ oxides; $\mathrm{Mn}$ is anomalous in this region also. 
The parallelism of belts M3a and M3b with the strike of the geologic formations, and the fact that their distinctive geochemistry can be explained by geologically and topographically separate systems of drainage basins, strongly suggests lithologic control of their geochemistry. However, there are individual samples suggestive of hydrothermal enrichment superimposed on these broad, lithologically controlled geochemical trends. Rock sample E145R located near the center of $\mathrm{M} 3 \mathrm{a}$, is a gray carbonate containing veins of quartz and pink dolomite. While this type of veining is common it indicates that hydrothermal circulation was indeed taking place whether or not it was responsible for mineralization. Rock sample E129R, located in the southwest corner of $\mathrm{M} 3 \mathrm{a}$, was gossan collected from a prospect pit and contained $10 \% \mathrm{Fe}$, $70 \mathrm{ppm} \mathrm{Pb}$, and $10 \mathrm{ppm} \mathrm{Sn}$. The presence of gossan is significant because it is a weathered residual of sulfide mineralization. The original mineralization might have been one of a number of deposit types known to occur in this geologic setting; these include porphyry Mo and $\mathrm{Cu}$, base- and precious-metal vein, and skarn deposits. This sample reinforces the adjacent

Mo-Zn-Cu-Cd-Ni-B-concentrate anomaly (E126, E127, and E128) placing this small region among those worthy of possible follow-up. Similarly, water samples E196W and E083W, although outside of $\mathrm{M3a}$ and $\mathrm{M} 3 \mathrm{~b}$, are of specjal interest because of their anomalous concentrations of $\mathrm{Mo}, \mathrm{F}^{-}$, and $\mathrm{SO}_{4}{ }^{-2}$ and $\mathrm{Mo}$, As, and $\mathrm{Mn}$, respectively. In the absence of nearby evaporite sequences it may be assumed that anomalous sulfate was derived from sulfide minerals. $\mathrm{SO}_{4}^{-2}$, Mo, and $\mathrm{F}^{-}$are commonly associated with Mo porphyry systems.

The geology and geochemistry of regions $\mathrm{M} 3 \mathrm{a}, \mathrm{M} 3 \mathrm{~b}$, and $\mathrm{M} 3 \mathrm{C}$ are very similar, and they are given the same resource favorability classification. M3a and M3b were discussed separately only because a ridge whose crest coincided with the Joana Limestone-Guilmette Formation contact separated basins draining two groups of formations, and made it possible to distinguish different geochemical signatures for M3a and M3b. The Paleozoic formations of regions $\mathrm{M} 3 \mathrm{a}$ and $\mathrm{M} 3 \mathrm{~b}$ continue to outcrop throughout most of region $\mathrm{M} 3 \mathrm{C}$. However, without topographic separation of the basins draining different formations, the signatures that characterized regions $M 3 a$ and $M 3 b$ overlap, and no clear pattern can be discerned. It appears that lithology plays as important a role in determining anomalies in M3c as it does in M3a and M3b. Thus anomalies in sediments are believed primarily related to the trace element chemistry of the Joana Limestone, Chainman Shale, and Ely Limestone, and anomalies in concentrates to the Guilmette and older formations.

The possibility that hydrothermal enrichment in certain elements has been supe rimposed on the lithology controlled trends cannot be eliminated. As mentioned earlier, the abundance of $\mathrm{Pb}$ in concentrates throughout the Egan WSA compared with the Riordan's Well WSA might be suggestive of different hydrothermal histories for the two areas (Hofstra and others, 1984). Certainly the existence of undiscovered Tertiary intrusions at depth is plausible, and the fracture system necessary for fluid circulation is present. The only strong factor loading for $\mathrm{Pb}$ is in stream sediment factor 2 $(\mathrm{Ca}, \mathrm{Mg}, \mathrm{Pb})$. This might be interpreted to mean either that the carbonates were rich in primary $\mathrm{Pb}$, or that the carbonates were particularly susceptible to $\mathrm{Pb}$ enrichment by hydrothermal activity. Less abundant than $\mathrm{Pb}$ are the scattered occurrences of anomalous $\mathrm{Ni}, \mathrm{Mo}, \mathrm{Sn}, \mathrm{Cd}, \mathrm{Cu}$, and $\mathrm{Mn}$ in concentrates. A number of springs (E086W, E260W, E259W, E257W, E407W, and E255E) were moderately anomalous in $\mathrm{Pb}, \mathrm{Cu}, \mathrm{Zn}, \mathrm{Mn}$, and As. Spring sample $\mathrm{E} 262 \mathrm{~W}$ is of somewhat greater interest because of its anomalous Mo and $\mathrm{SO}^{-2}$. 
Region M4 in the east-central portion of the study area contains three significant rock samples (E152R, E160R, and E163R). E152R was collected from a dike containing volcanic breccia fragments of felsic to intermediate composition. It contained detectable $\mathrm{Au}(<0.05 \mathrm{ppm})$, As ( $>200 \mathrm{ppm})$, as well as anomalous Sb and Mn. E160R and E163R were, respectively, gray siltite with jarosite-limonite fracture coatings, and vuggy red-brown-green jasperoid. E160R was anomalous in $\mathrm{Ag}$ and $\mathrm{Sb}$, and E163R contained anomalous $\mathrm{As}, \mathrm{Sb}, \mathrm{Zn}$, $\mathrm{Pb}, \mathrm{Cu}, \mathrm{Mn}$, and Mo. These three rock samples are aligned roughly north-south and E152R lies within half a mile of a $30 \mathrm{ppm} \mathrm{Ag}$ value in concentrates at site E158. At site E158 anomalous concentrations were found only for silver;

however, rock sample E152R, which contained detectable $A u$, is within a mile to the west. Anomalous values for $\mathrm{Cu}, \mathrm{Mn}$, and factor 3 ( $\mathrm{Cu}, \mathrm{As}, \mathrm{Ni}$ ) in sediments and $\mathrm{Pb}, \mathrm{Sn}, \mathrm{Mn}$, and factor 6 ( $\mathrm{Co}, \mathrm{Cu}, \mathrm{Pb}, \mathrm{Zn})$ in concentrates in the vicinity of E158 provide some reinforcement of the Ag anomaly; however, the possible role of Mn oxides in concentrating elements such as $\mathrm{Cu}$ cannot be dismissed. Approximately one mile northwest of sample E158R anomalous $\mathrm{Cu}$ and $\mathrm{Mn}$ occur in sediments. At three sites two miles east of E158 anomalous $\mathrm{Cu}$ and factor 3 ( $\mathrm{Cu}, \mathrm{As}, \mathrm{Ni}$ ) occur in sediments; and anomalous $\mathrm{Pb}, \mathrm{Mn}$, and factor 6 ( $\mathrm{Co}, \mathrm{Cu}$, $\mathrm{Pb}, \mathrm{Zn}$ ) occur in concentrates.

In the immediate vicinity of rock sample E163R, a water sample, E406W, contains anomalous $\mathrm{SO}_{4}{ }^{-2}, \mathrm{~Pb}, \mathrm{Zn}, \mathrm{Cu}$, and $\mathrm{Mn}$. To the north, an anomalous concentrate sample $\mathrm{E} 162$ is enriched in $\mathrm{Cu}, \mathrm{Ni}$, and $\mathrm{B}$. Northeast of E163R there are anomalous values of $\mathrm{Cu}, \mathrm{As}$, and $\mathrm{Ni}$ and factor 3 ( $\mathrm{Cu}, \mathrm{As}, \mathrm{Ni}$ ) in sediments.

The three samples anomalous in $\mathrm{Au}, \mathrm{Ag}, \mathrm{As}, \mathrm{Sb}, \mathrm{Pb}, \mathrm{Zn}, \mathrm{Cu}, \mathrm{Mo}$, and $\mathrm{Mn}$, combined with a high silver value in sediment, and a spring water sample containing anomalous $\mathrm{SO}_{4}^{-2}$ and base metals, are strongly suggestive of several types of mineralization all known to occur in similar geologic settings. Based on the suites of anomalous elements in region M4, porphyry copper and molybdenum are among the deposit types suggested; the Ruth porphyry copper deposit in the northern Egan Range (about five miles west of Ely) and the Ellison district porphyry molybdenum target are nearby examples of these deposit types. Precious metal anomalies may be indicative of base/precious metal skarn deposits similar to the one in the Ward district, approximately ten miles north of the study area in the Egan Range. Finally, base- and precious-metal vein deposits are commonly associated with anomalous $\mathrm{Au}, \mathrm{Ag}$, $\mathrm{As}, \mathrm{Sb}, \mathrm{Pb}, \mathrm{Zn}$, and $\mathrm{Cu}$; the Ellison mining district provides a nearby example of this type of mineralization in the same geologic formations.

Region M5 consists of Quaternary alluvium at the margins of the study area. Samples collected from these areas probably do not reflect underlying geologic conditions; classification and the rare instances of anomalous element concentrations might be explained by coprecipitation phenomena.

\section{METALLIC MINERAL RESOURCE FAVORABILITY}

The regions designated M1 through M5 refer to the map in figure 3.

M1-4D is known to contain base- and precious-metal vein mineralization, which although currently non-economic, is a resource of $\mathrm{Cu}, \mathrm{Pb}, \mathrm{Zn}, \mathrm{Ag}$, and possibly Au. In addition there is reportedly potential for a molybdenum porphyry system at depth. 
M2-4D is an area known to contain currently subeconomic resources in disseminated deposits of $\mathrm{Au}$ and $\mathrm{Ag}$.

M3a-2C and M3b-2C are belts defined by anomalous concentrations of suites of elements believed to reflect the relatively high background of these elements in the surrounding outcrop. The low favorability assessment does not reflect the possibility of mineralization where hydrothermal circulation and alteration may have enriched certain elements.

M3C-2C contains primarily the same units found in regions $M 3 a$ and M3b; the $2 \mathrm{C}$ favorability ranking is based on the same reasoning given for areas $\mathrm{M} 3 \mathrm{a}$ and M3b.

M4-3C: Three rock samples containing anomalous $\mathrm{Au}, \mathrm{Ag}, \mathrm{As}$, $\mathrm{Sb}$, and base metals, reinforced by an anomalous water sample, and a value of $30 \mathrm{ppm} \mathrm{Ag}$ in concentrates differentiate this region from the surrounding areas ranked $2 \mathrm{C}$. The elements anomalous in this area coincide most closely with the suite associated with base-metal vein deposits (see table 2); however skarn and porphyry mineralization are also possible, given the geologic setting and the geochemistry.

M5-1B is an area of Quaternary alluvium where the few samples probably do not reflect the underlying geologic conditions. With only minor exceptions, samples from this area contained no anomalous element concentrations.

\section{RECOMMENDATIONS}

Rock sample E129R, a gossan containing $10 \% \mathrm{Fe}, 70 \mathrm{ppm} \mathrm{Pb}$, and $10 \mathrm{ppm} \mathrm{Sn}$, and water samples E196W and E083W anomalous in $\mathrm{Mo}^{-} \mathrm{F}^{-}$, and $\mathrm{SO}_{4}^{-2}$ and $\mathrm{Mo}, \mathrm{As}$, and $M n$ respectively, were mentioned in discussion of region $M 33 b$. These samples are suggestive of mineralization, however, in the authors' judgement, are not significant enough to warrant separate zones of higher favorability. Although these samples fall in zones ranked $2 \mathrm{C}$, a thorough follow-up study would include mapping of geology and alteration, and a more detailed geochemical survey of the sections containing these samples could upgrade, or at least improve confidence, in the ranking.

Further investigation of the region ranked $3 C$, such as detailed geologic mapping, and more detailed geochemical study, is recommended on the basis of anomalous samples in three different media (water, rock, and sediment) which provide direct if not abundant evidence of mineralization. 
LEGEND

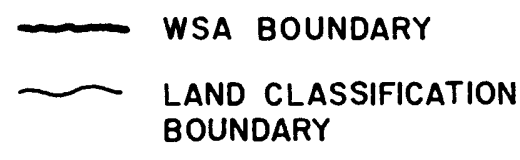

M3-2C METALLIC MINERAL RESOURCE AREAFAVORABILITY CLASSIFICATION (TABLE 1)
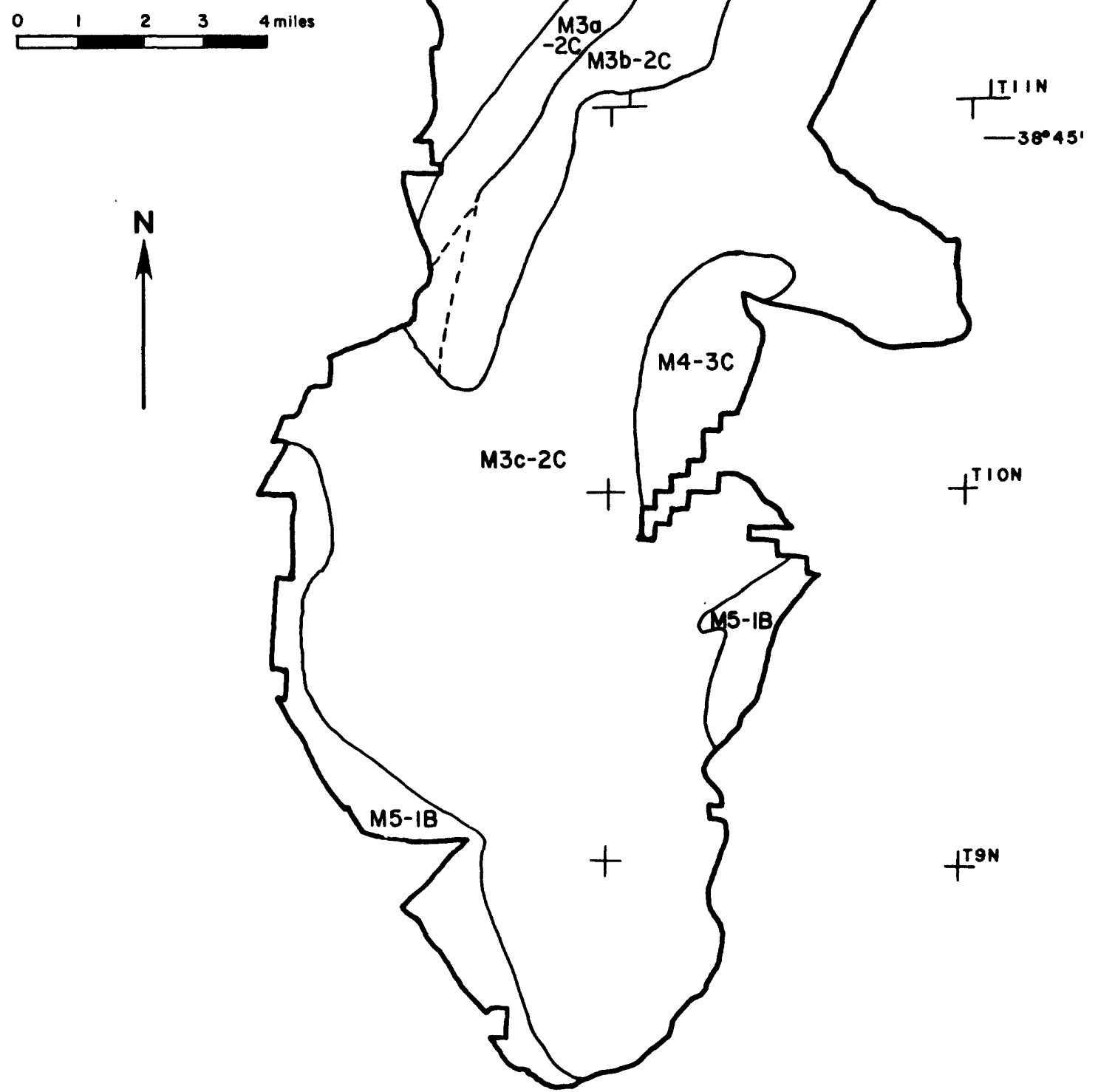

FIGURE 3-METALLIC MINERAL RESOURCE FAVORABILITY MAP, SOUTH EGAN RANGE WSA NV 040-168, WHITE PINE, LINCOLN, NYE COUNTIES, NEVADA 


\section{REFERENCES CITED}

Aruscavage, P., 1977, Determination of arsenic, antimony, and selenium in coal by atomic absorption spectrometry with a graphite tube atomizer: U.S. Geological Survey Journal of Research, v. 5, no. 4, p. 405-408.

Brobst, Donald A., and Pratt, W. P., 1973, in Brobst, D. A. and W. P. Pratt, eds., United States Mineral Resources: U.S. Geological Survey Professional Paper 820, p. 1-8.

Davis, John C., 1973, Statistics and data analysis in geology: New York, John Wiley and Sons, Inc., $547 \mathrm{p}$.

Fisher, Don, and Juilliand, Jean, 1983, BLM studies millions of acres in western U.S. for possible wilderness designation: Mining Engineering, v. 35 , no. 10 , p. 1409-1410.

Fishman, M. J., and Pyen, G., 1979, Determination of selected anions in water by ion chromatography: U.S. Geological Survey Water Resources Investigations $79-101,30 \mathrm{p}$.

Gans, P. B., and Miller, E. L., 1983, Style of mid-Tertiary extension in eastcentral Nevada: Utah Geological and Mineralogical Survey, Special Studies 59, Guidebook--Part I, p. 107-160.

Great Basin GEM Joint Venture, 1982, Egan/Mt. Grafton G-E-M Resources Area (GRA No. NV-14) Technical Report (NV 040-168, 040-169, 040-172): Bureau of Land Management (Denver), Final Draft, December 1982.

Grimes, D. J., and Marranzino, A. P., 1968, Direct-current arc and alternating-current spark emission spectrographic field methods for semiquantitative analysis of geologic materials: U.S. Geological Survey Circular 591.

Hofstra, A. H., Rowan, E. L., and Day, G. W., 1984, Reconnaissance geochemical assessment of metallic mineral resource potential, Riordan's Well Wilderness Study Area (NV 040-166), Nye County, Nevada: U.S. Geological Survey Open-File Report 84- (in press).

Hose, R. K., Blake, M. C., and Roscoe, S., 1976, Geology and mineral resources of White Pine County, Nevada: Nevada Bureau of Mines and Geology Bulletin 85.

Kellogg, H. E., 1963, Paleozoic stratigraphy of the Southern Egan Range, Nevada: Geological Society of America Bulletin, v. 74, p. 685-708.

1964, Cenozoic stratigraphy and structure of the Southern Egan Range, Nevada: Geological Society of America Bulletin, v. 75, p. 949-968.

Mckelvey, V. E., 1973, Mineral resource estimates and public policy, in Brobst, D. A. and Pratt, W. P., eds., United States Mineral Resources: U.S. Geological Survey Professional Paper 820, Chapter 1, p. 9-19. 
Miesch, A. T., 1976, Geochemical survey of Missouri--methods of sampling, laboratory analysis, and statistical reduction of data: U.S. Geological Survey Professional Paper 954-A.

Motooka, J. M., and Grimes, D. J., 1976, Analytical precision of one-sixth order semiquantitative spectrographic analysis: U.S. Geological Survey Circular 738.

Orion Research Inc., 1973, Orion Research Analytical Methods Guide, 7th edition: Cambridge, Massachusetts, $20 \mathrm{p}$.

Perkin-Elmer Corporation, 1976, Analytical methods for atomic absorption spectrophotometry: Norwalk, Connecticut, p.

Perkin-Elmer Corporation, 1977, Analytical methods for atomic absorption spectrophotometry, using the HGA graphite furnace: Norwalk, Connecticut, 586 p.

Rose, A. W., Hawkes, H. E., and Webb, J. S., 1979, Geochemistry in mineral exploration: New York, Academic Press, p.

Skougstad, M. W., Fishman, M. J., Friedman, L. C., Erdman, D. E., and Duncan, S. S., 1979, Methods for determination of inorganic substances in water and fluvial sediments: Techniques of Water-Resource Investigations of the United States Geological Survey, Chapter A-I.

Thompson, C. E., Nakagawa, H. M., and Van Sickle, G. H., 1968, Rapid analysis for gold in geologic materials, in Geological Survey research 1968: U.S. Geological Survey Professional Paper 600-B, p. B130-B132.

Tschanz, C. M., and Pampeyan, E. H., 1970, Geology and mineral deposits of Lincoln County, Nevada: Nevada Bureau of Mines and Geology Bulletin 73.

VanTrump, G., and Miesch, A. T., 1977, The U.S. Geological Survey's RASSSTATPAC system for management and statistical reduction of geochemical data: Computers and Geoscience, v. 3, p. 475-488.

Viets, J. G., 1978, Determination of silver, bismuth, cadmium, copper, lead, and zinc in geological materials by atomic-absorption spectrometry with tricaprylylmethylammonium chloride: Analytical Chemistry, v. 52, p. 1097-1101. 
APPENDIX.--Results of Chemical Analyses 


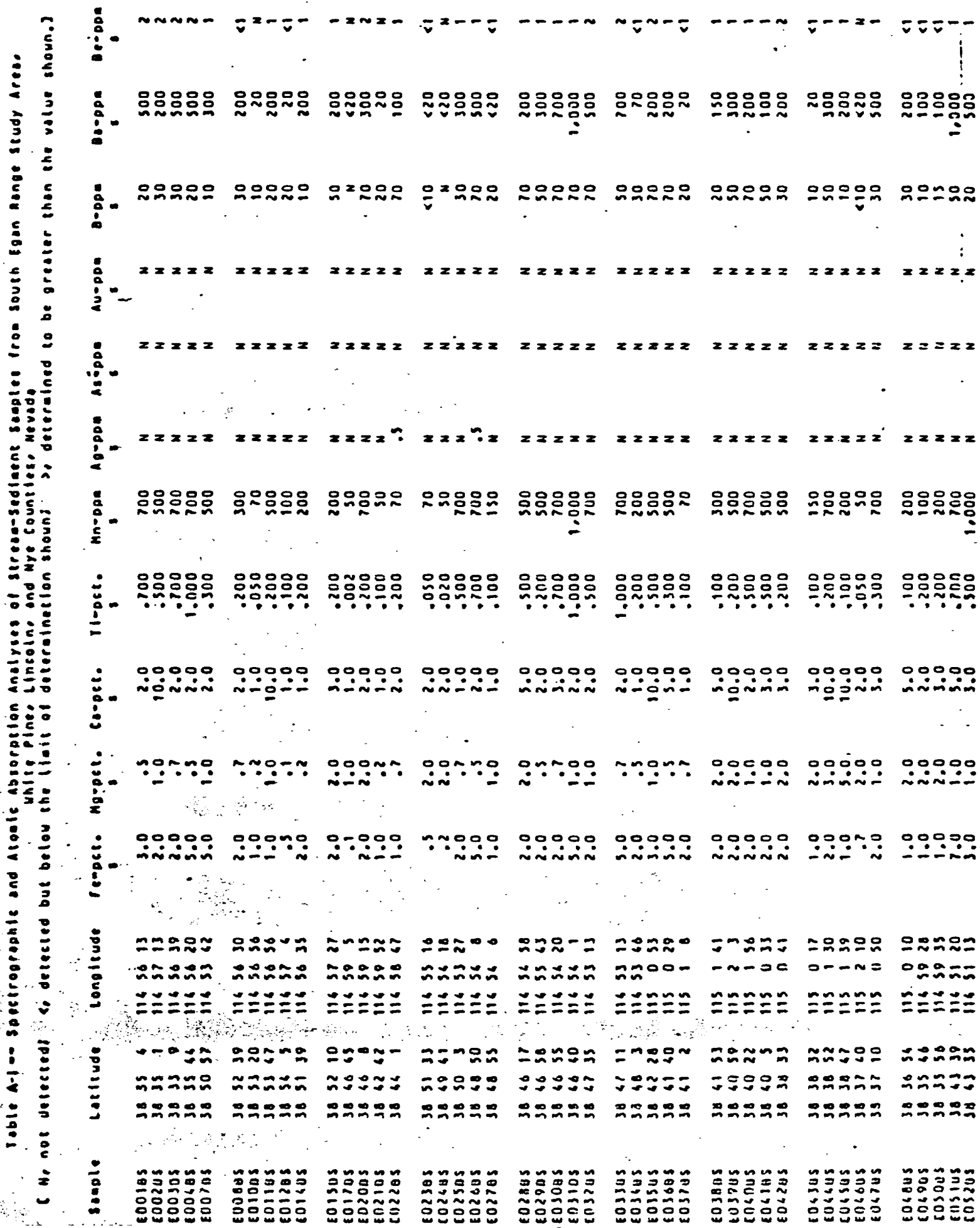




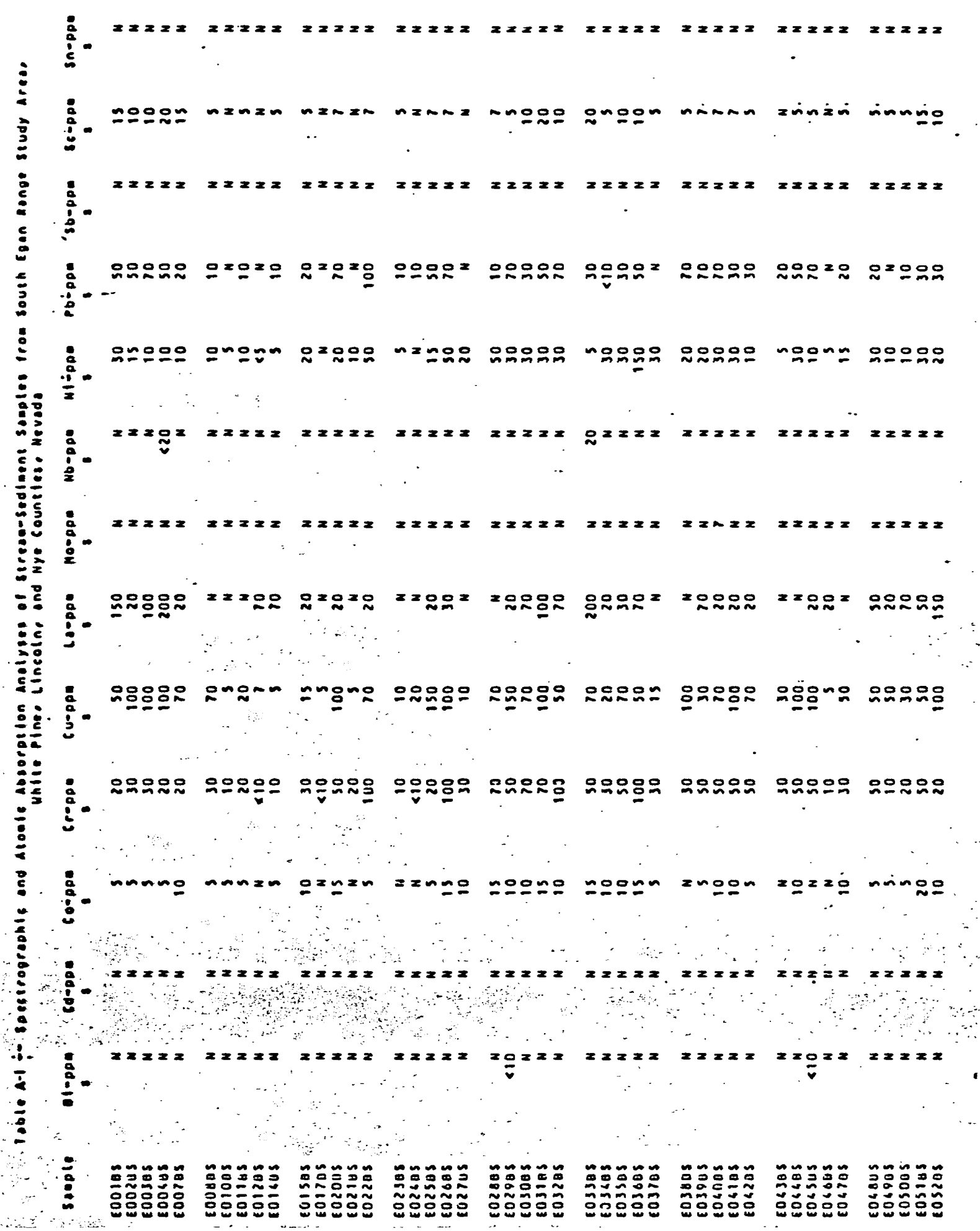




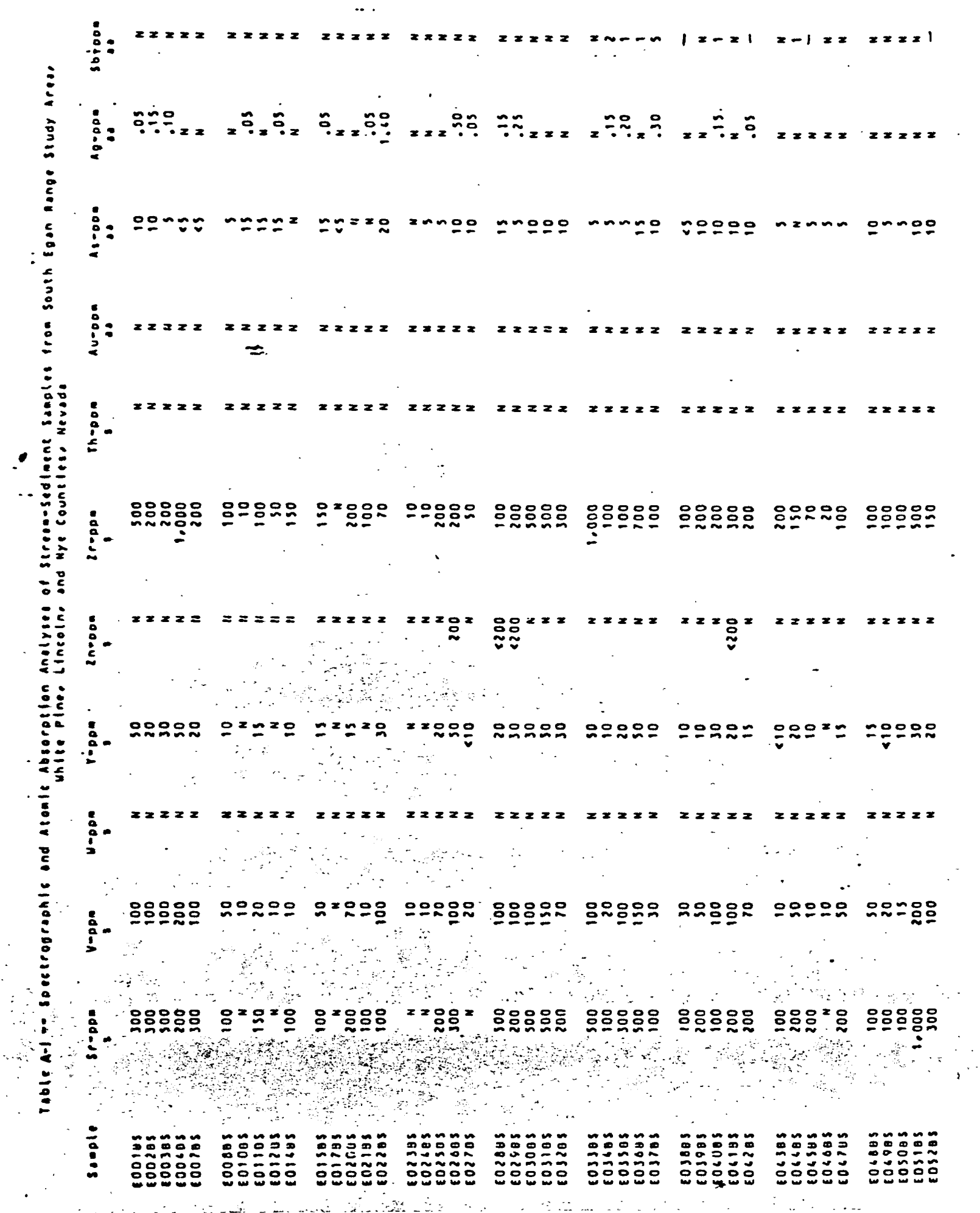




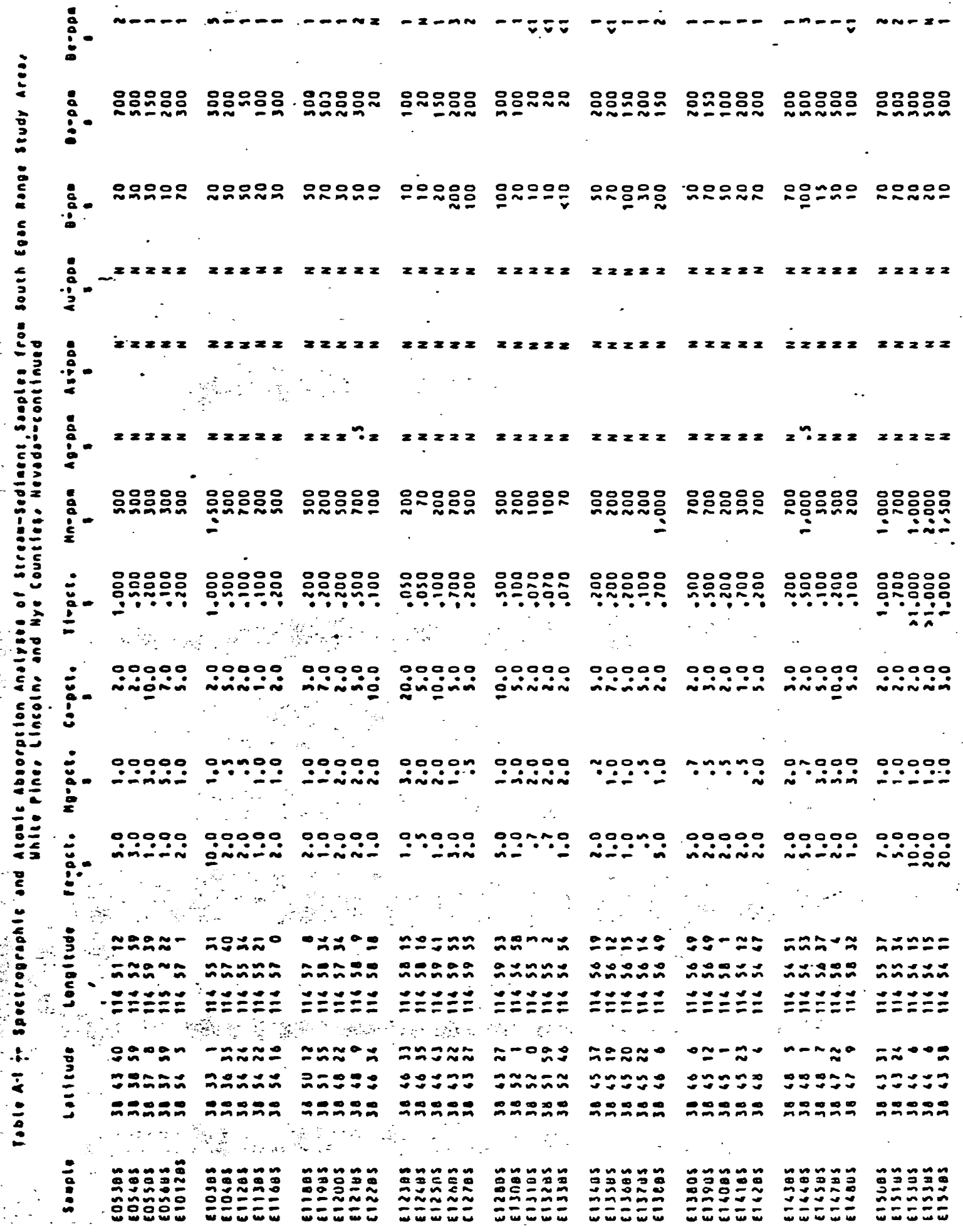




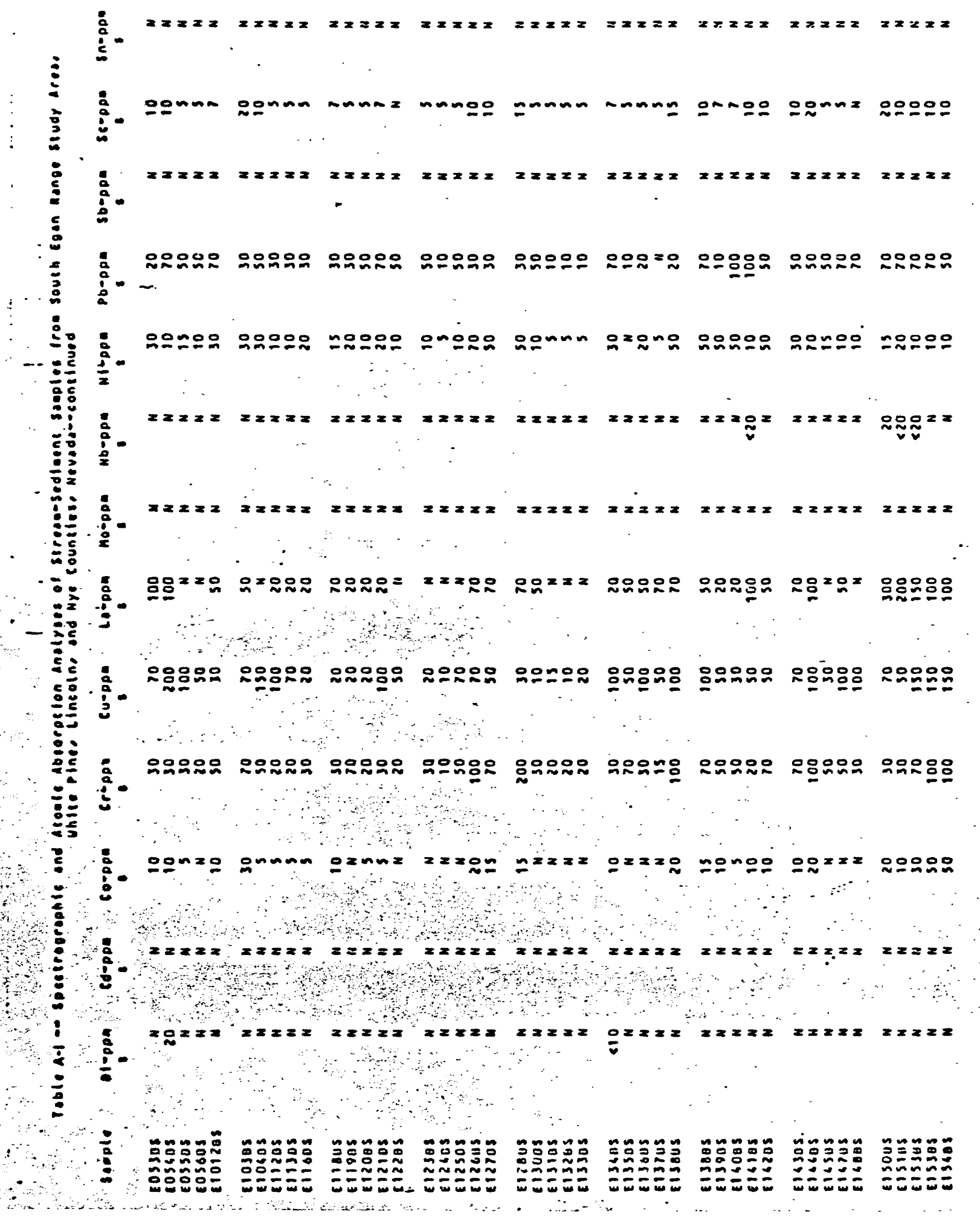




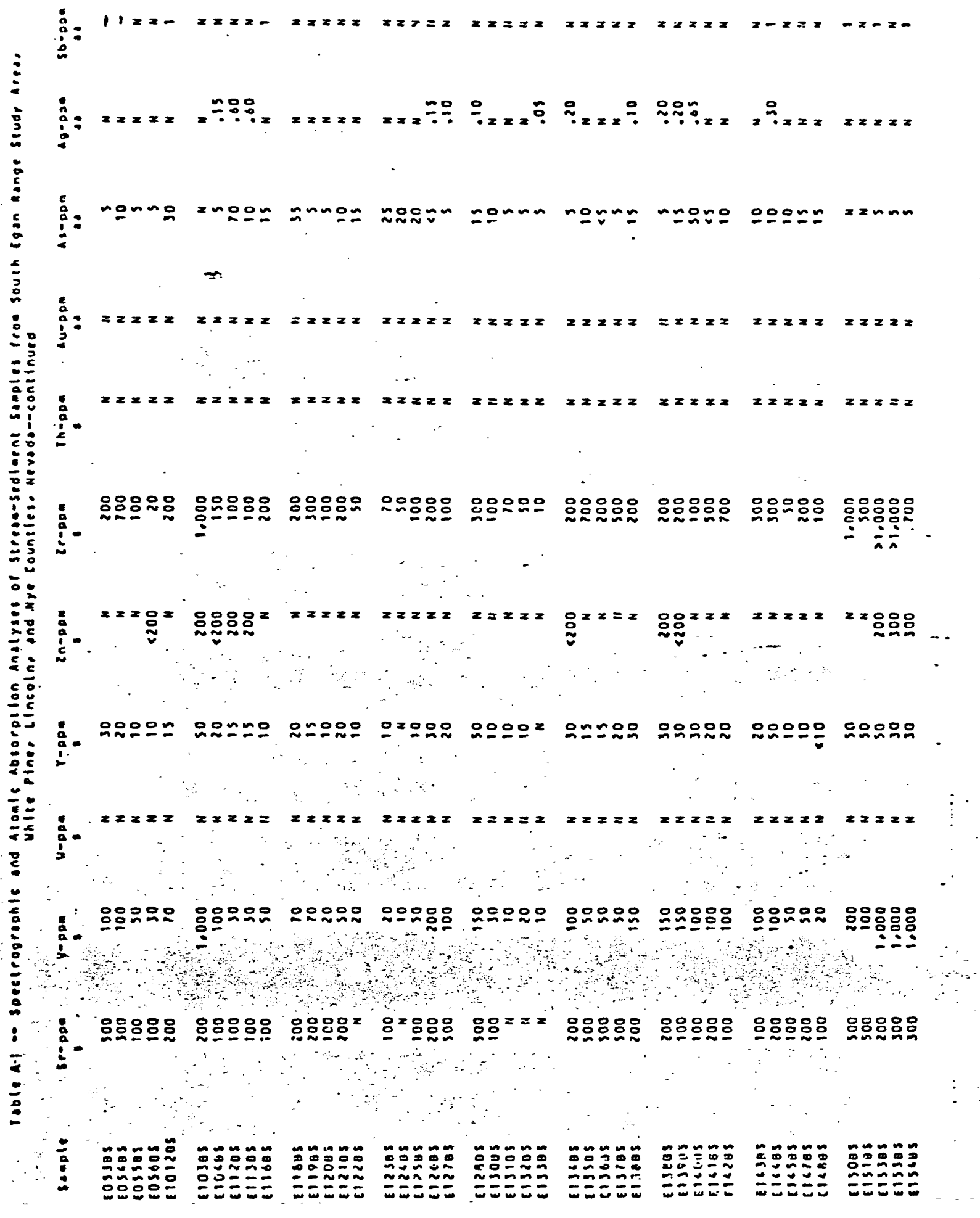




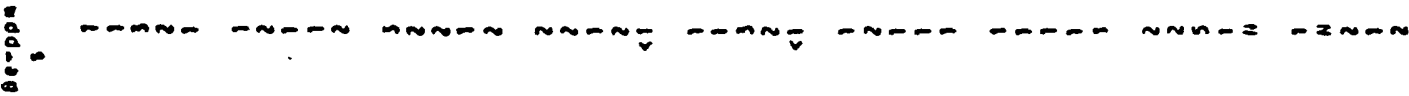

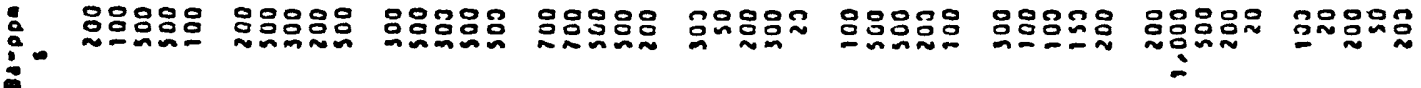

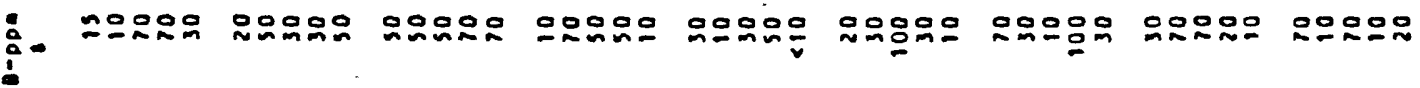

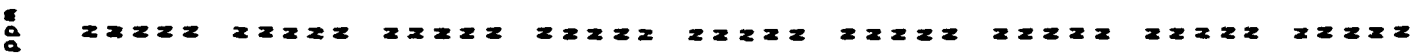
in

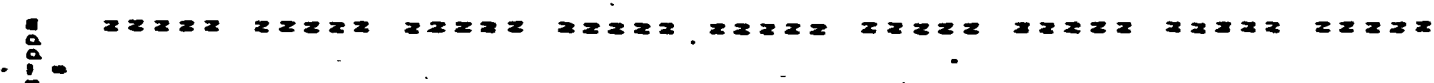

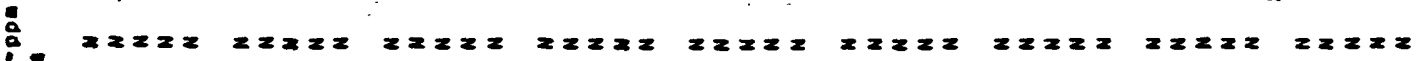

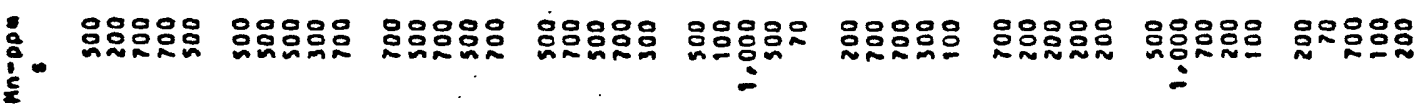

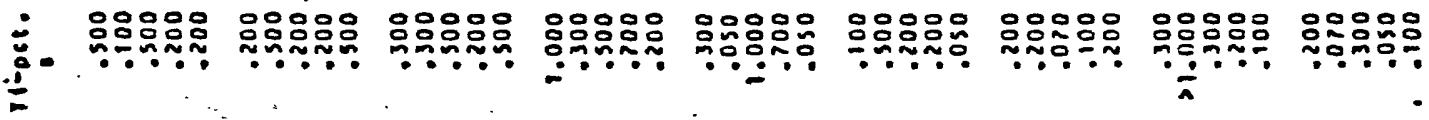
$\therefore 000001000000000000000000000000000000000000000$

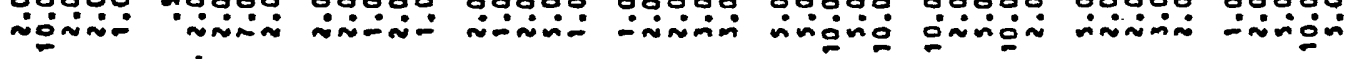

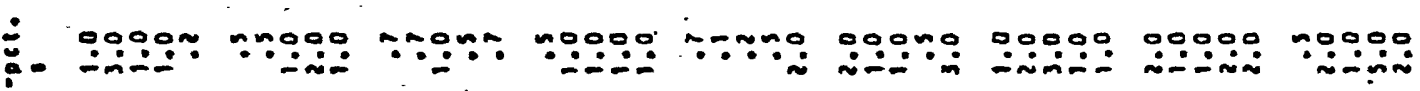
ڤ.

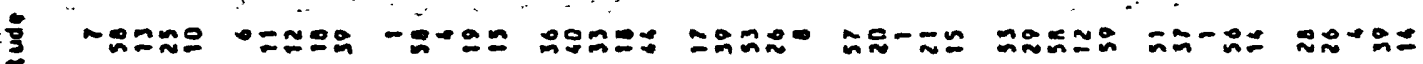

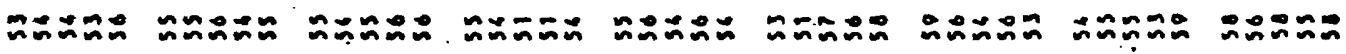

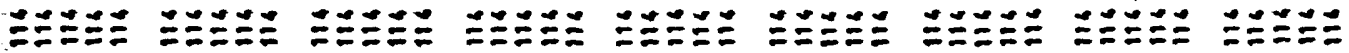

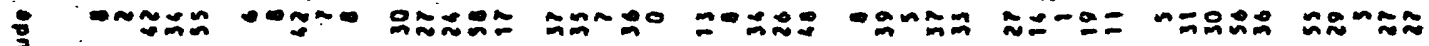

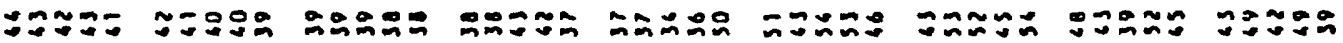

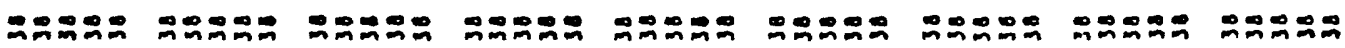

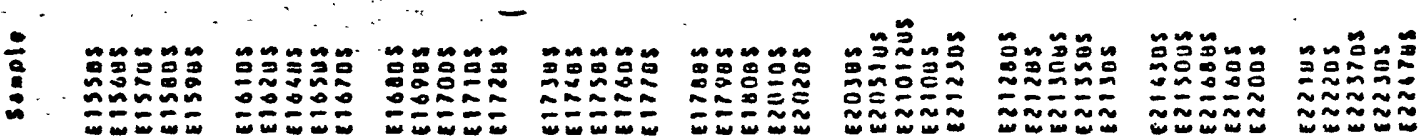




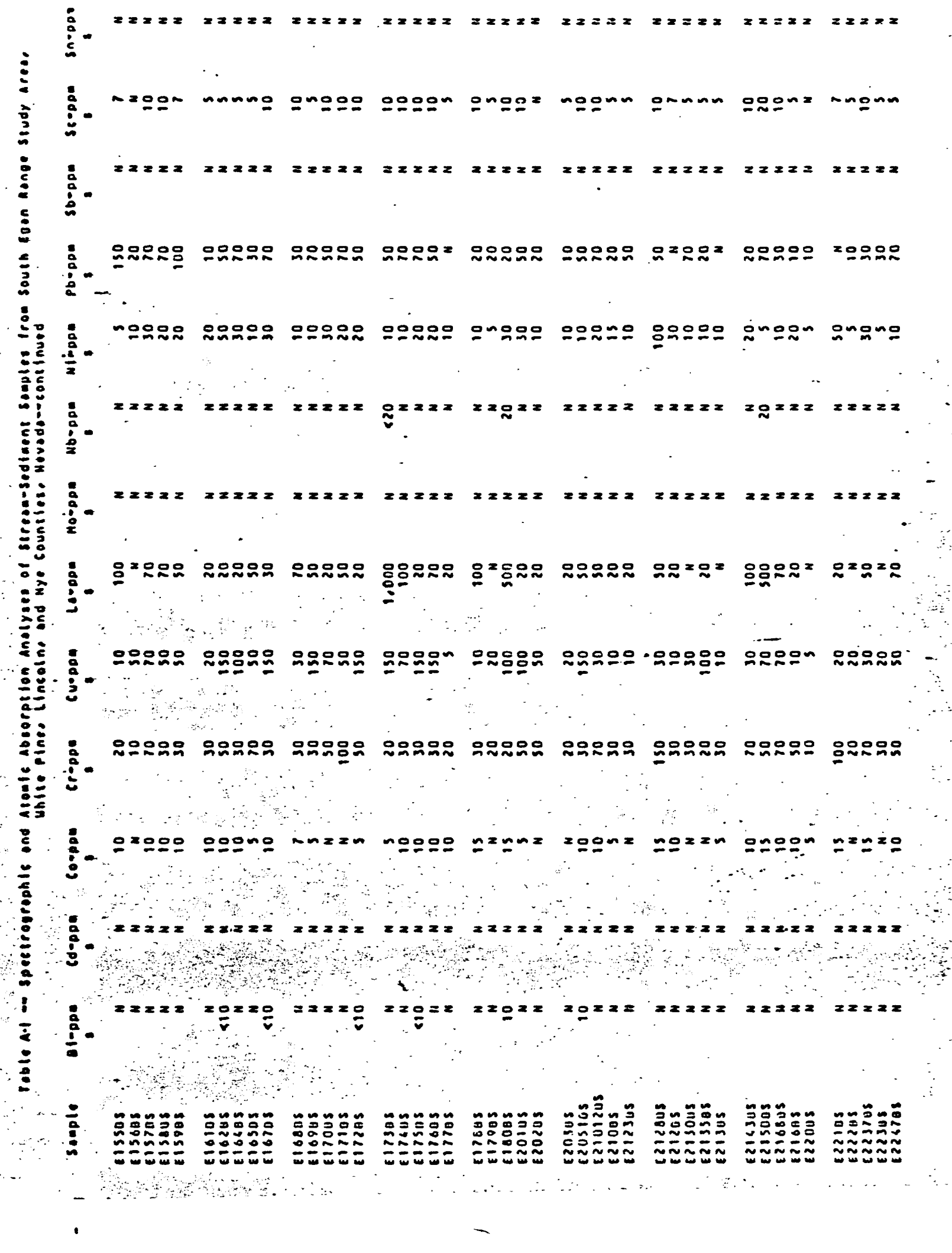




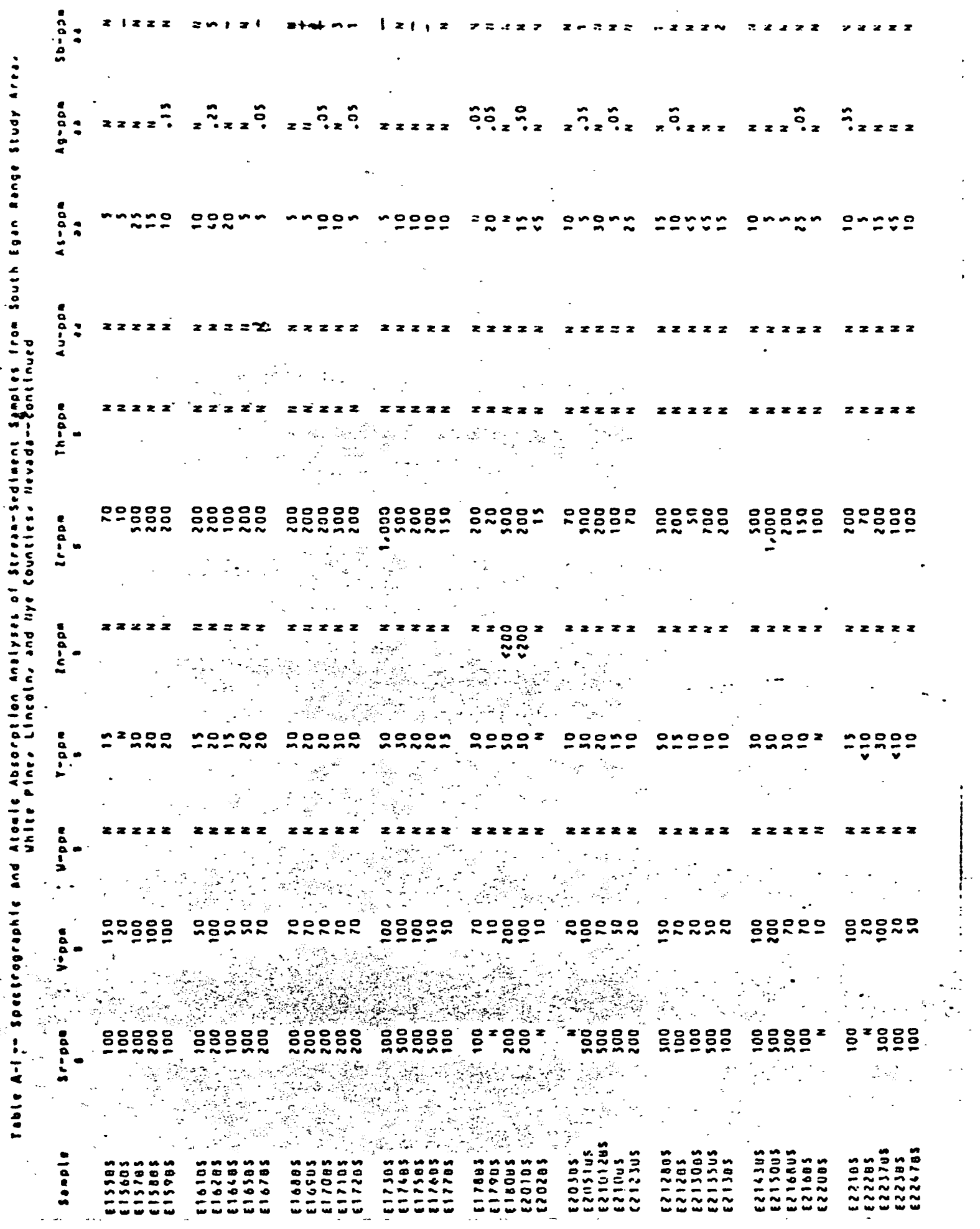




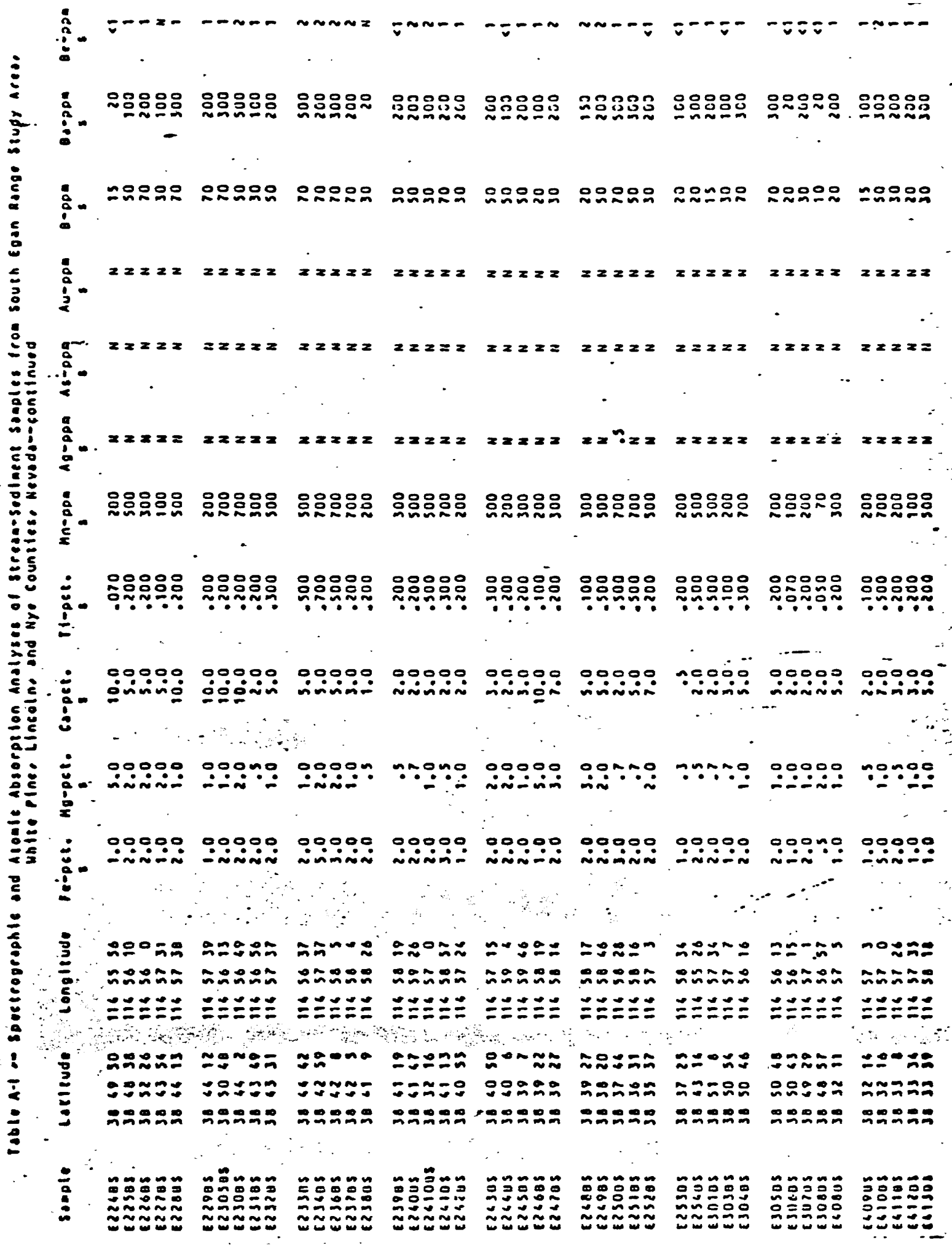




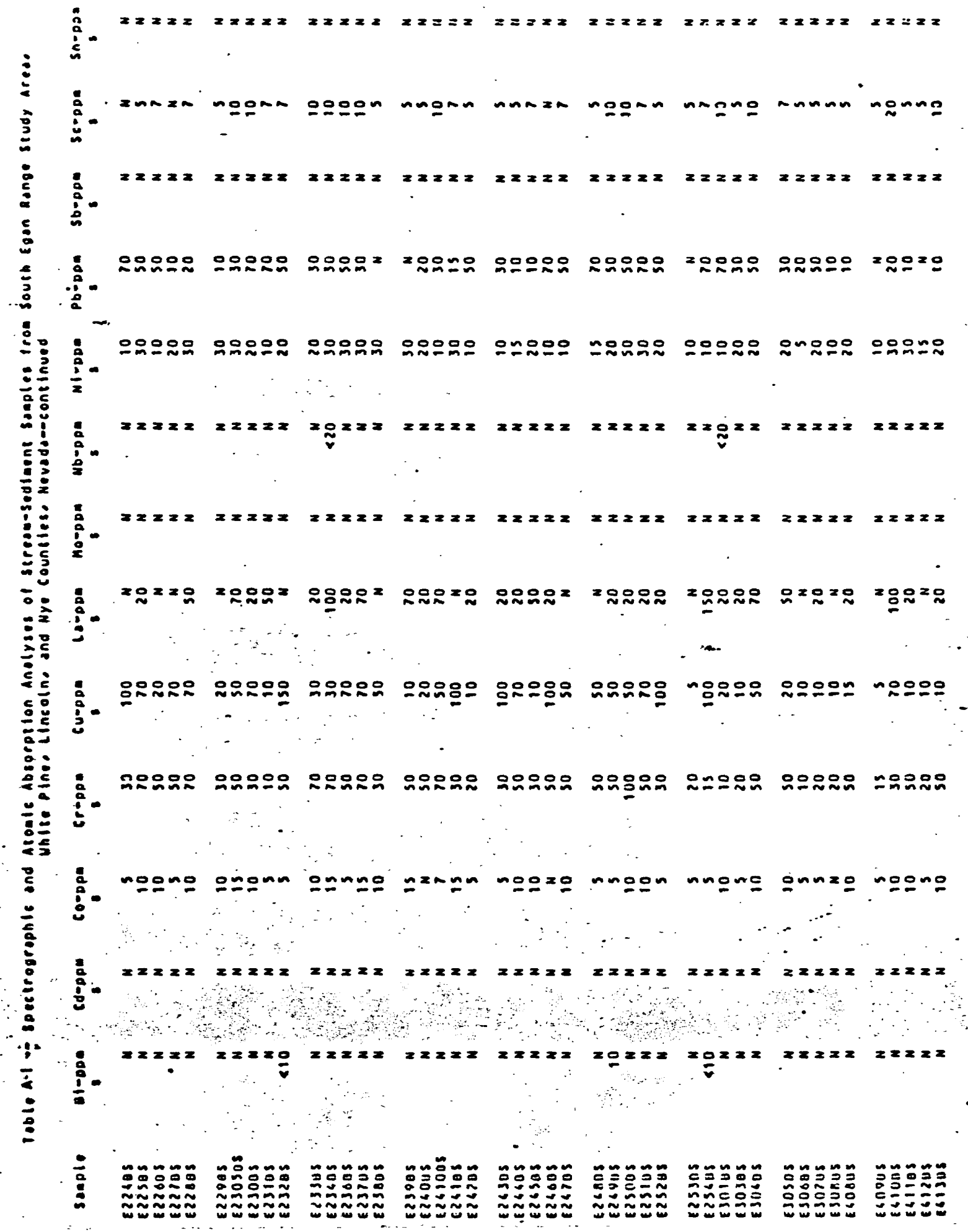




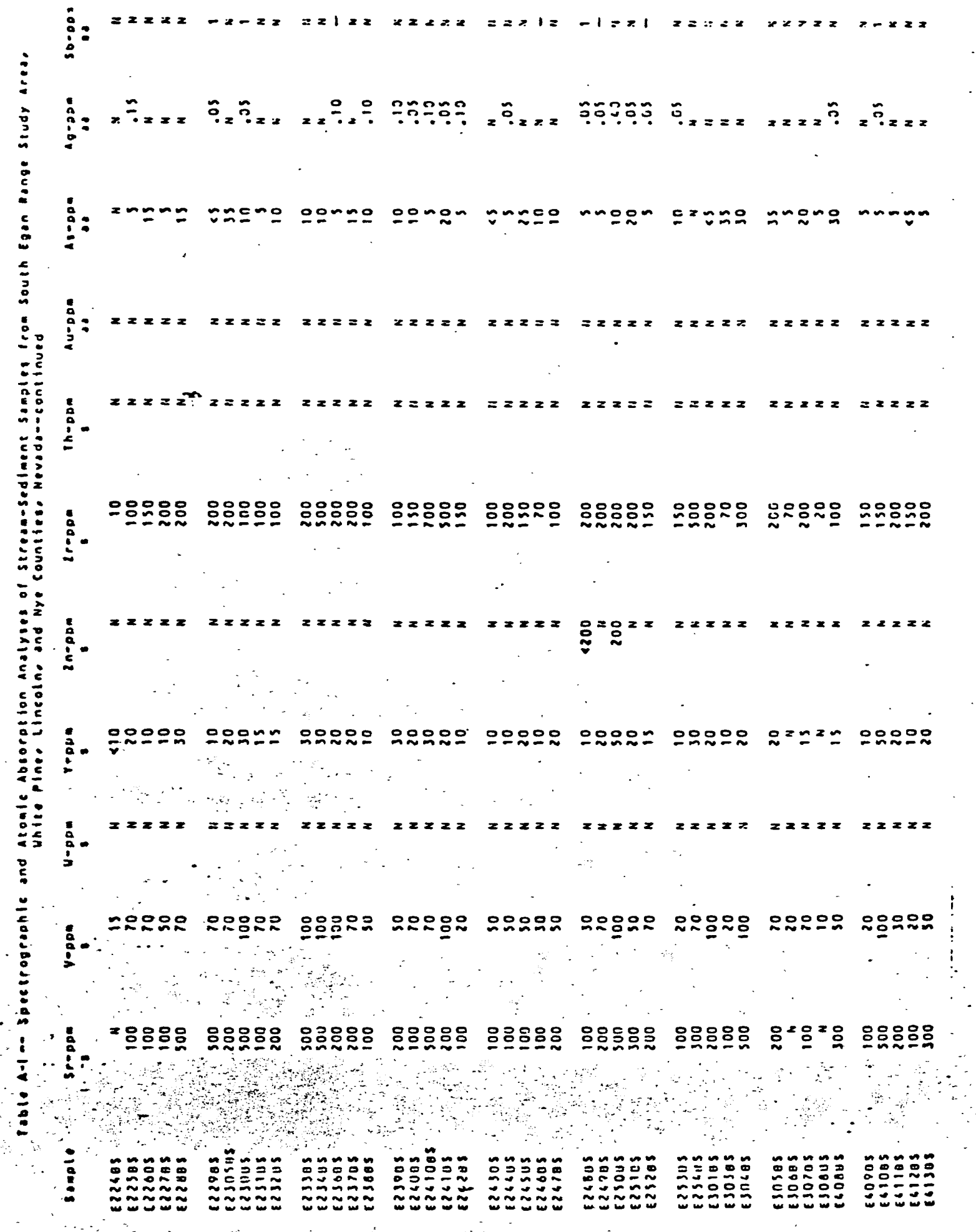




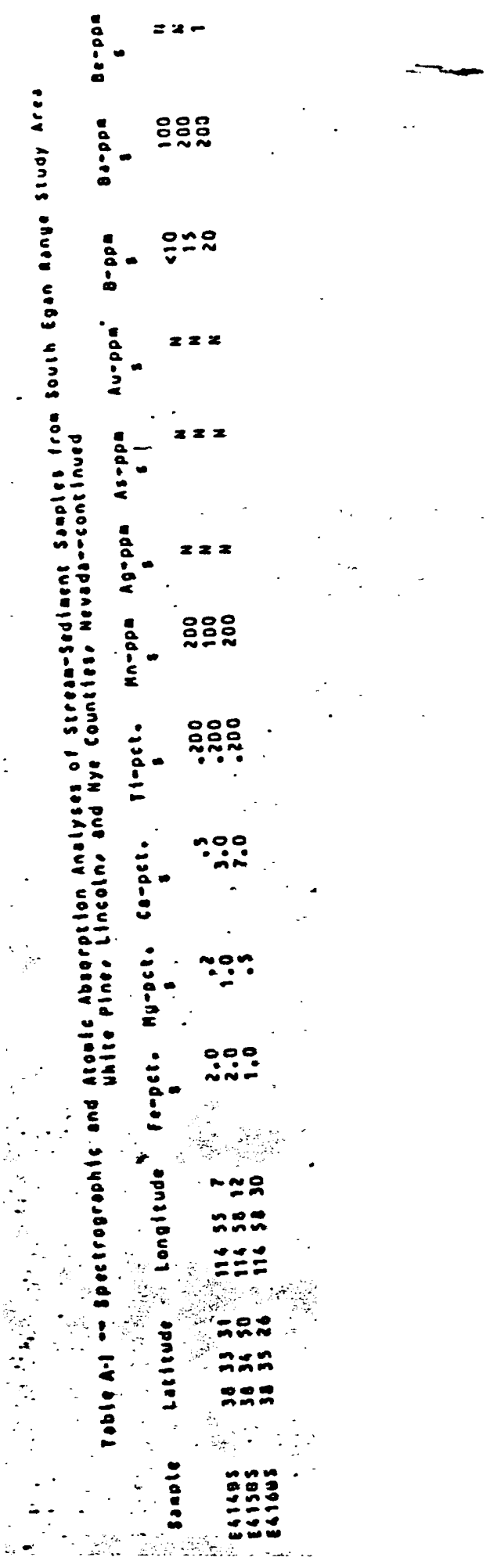




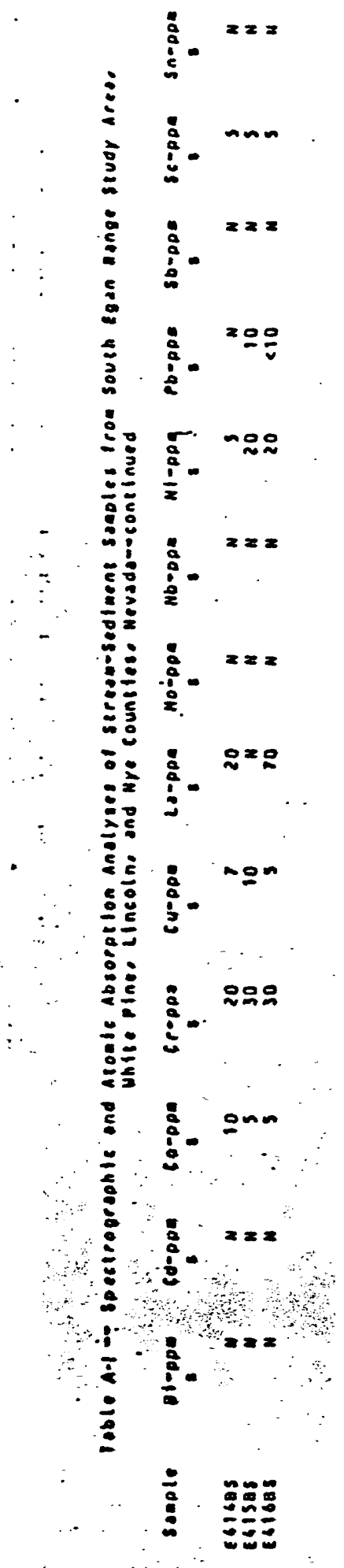




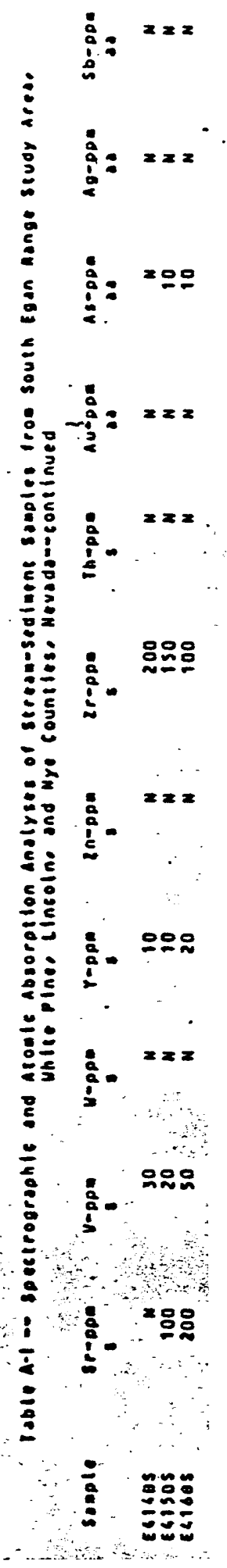




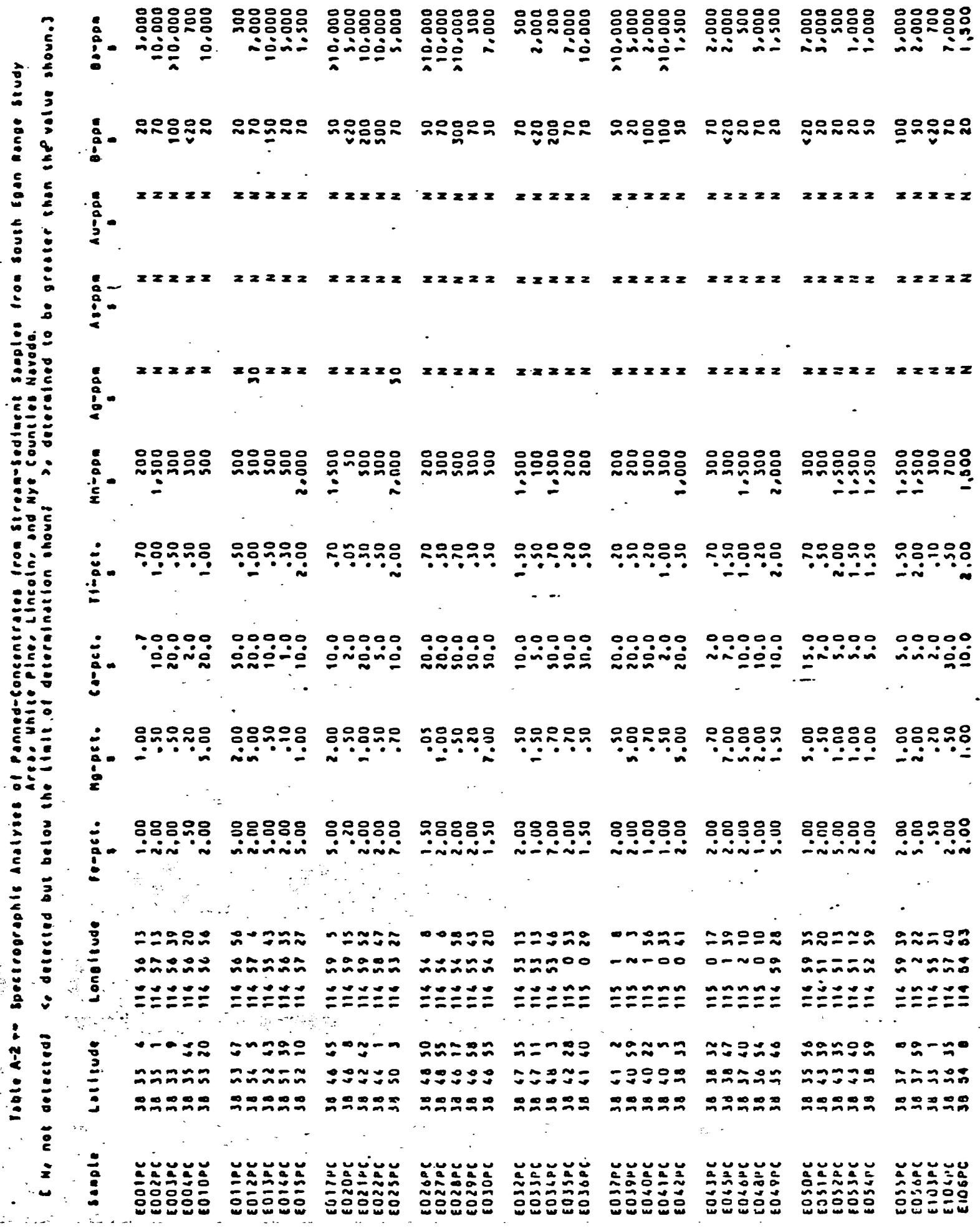


:

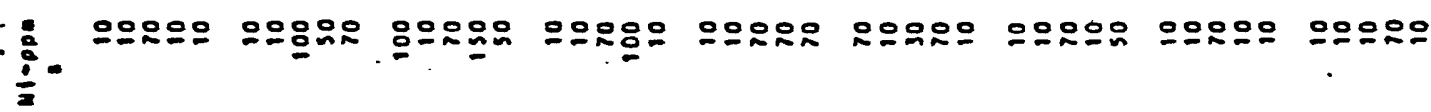

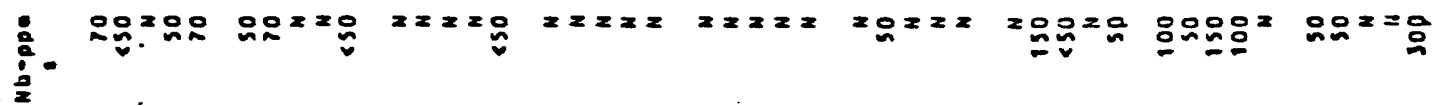

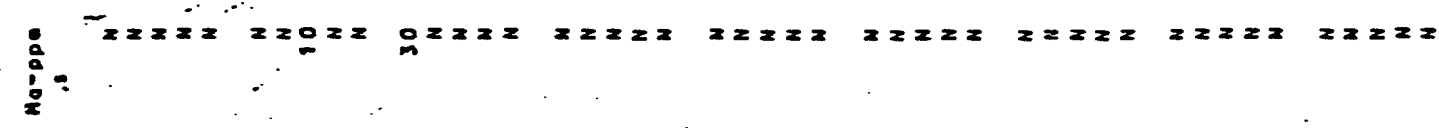

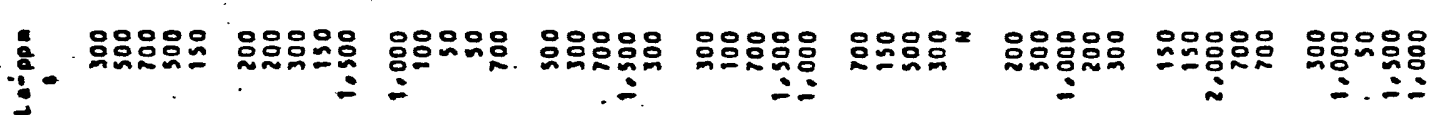

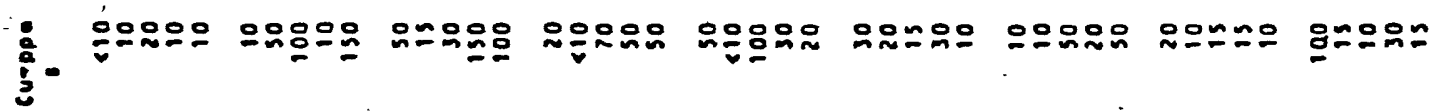
道

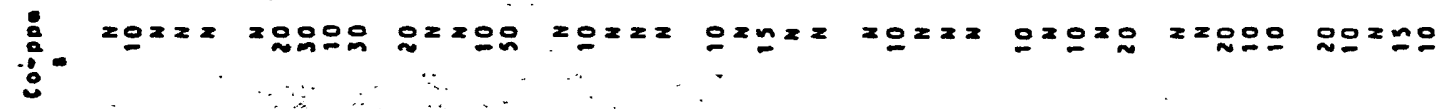

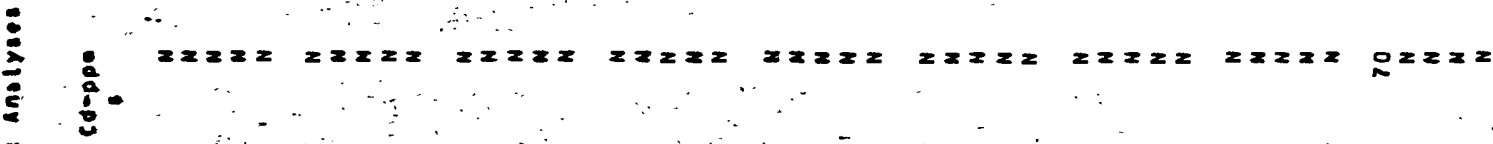

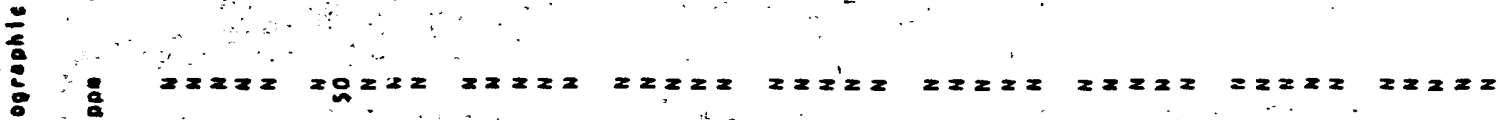
$-$

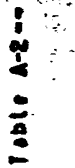

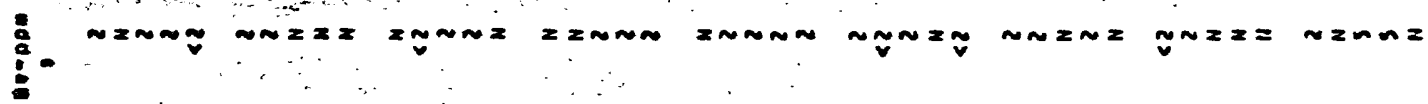
告 


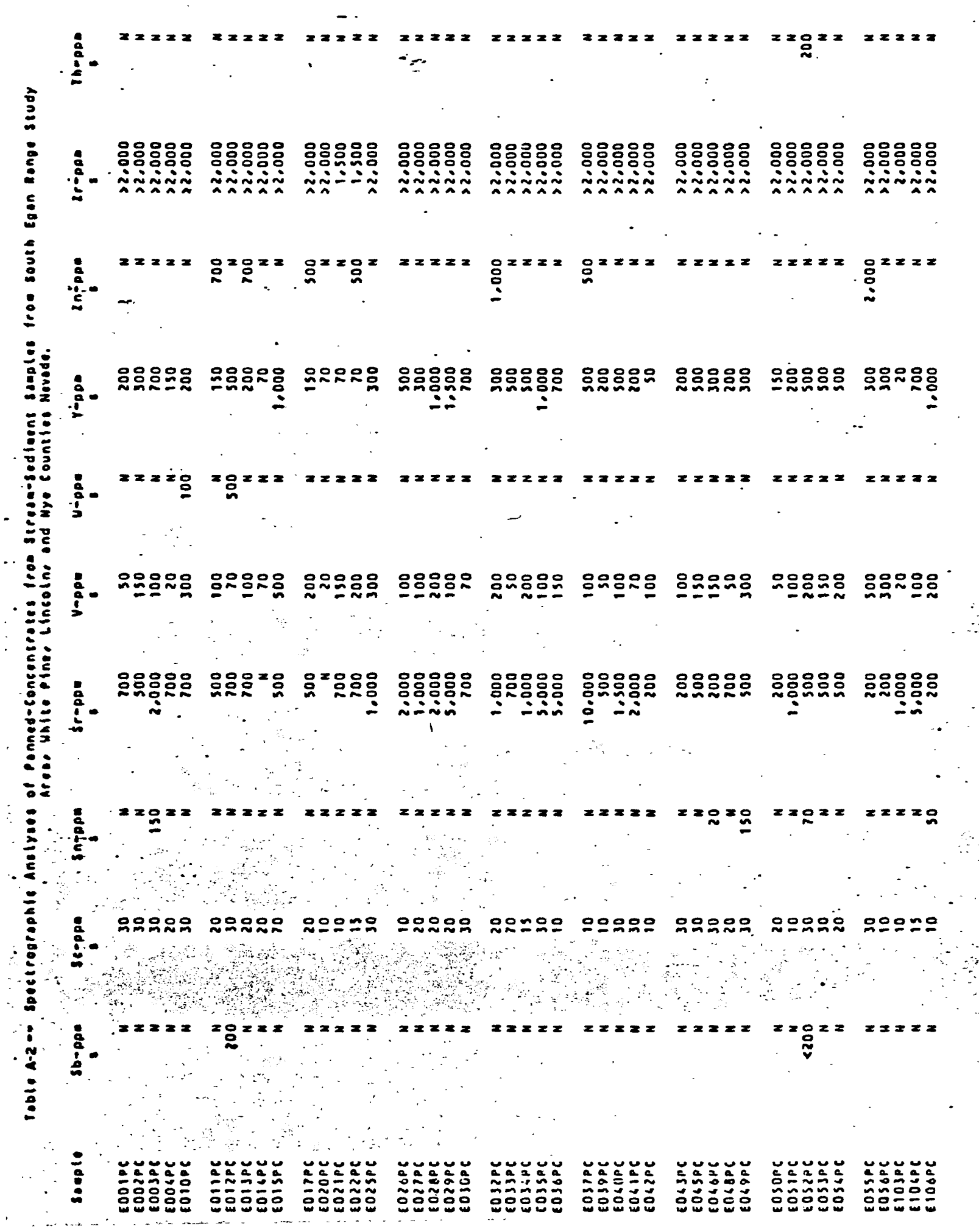




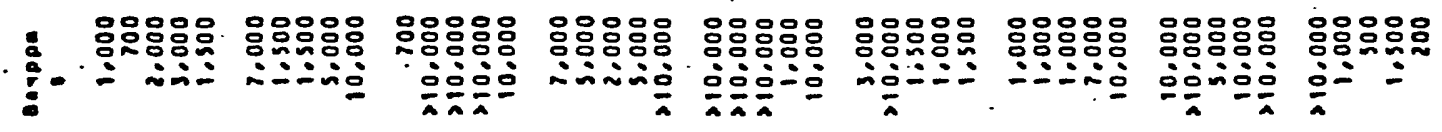

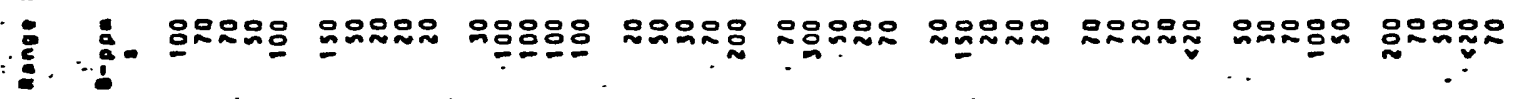$$
\text { : }
$$

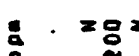

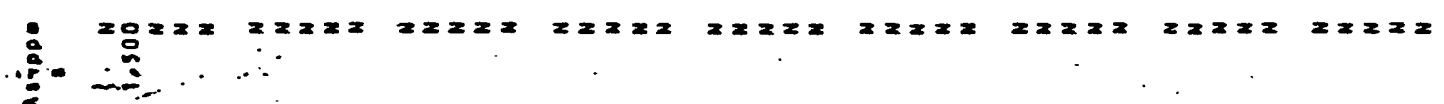

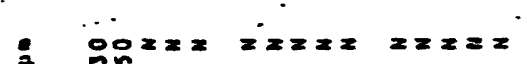

$:-$

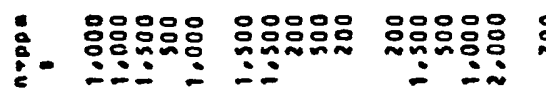

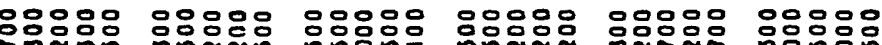

㱏 $\underline{-1}$ ـ

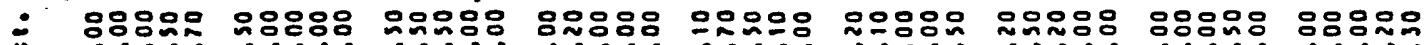
-

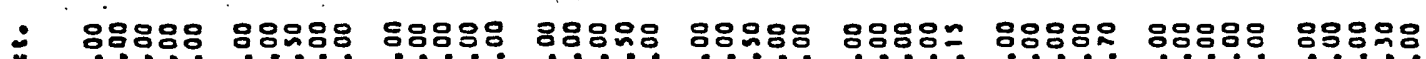

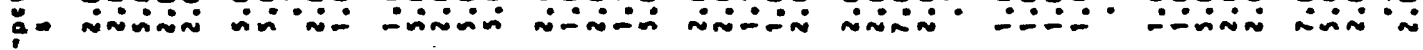

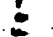

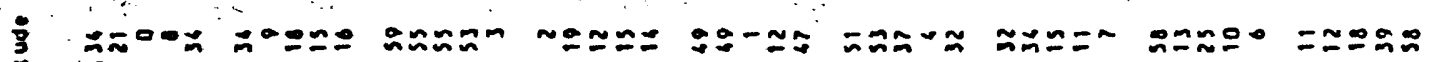

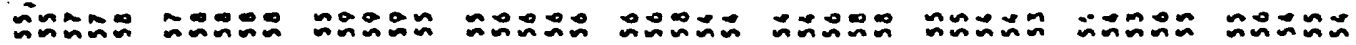

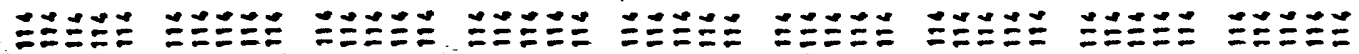

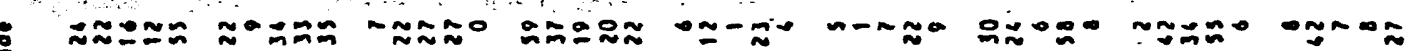

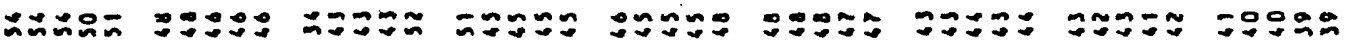

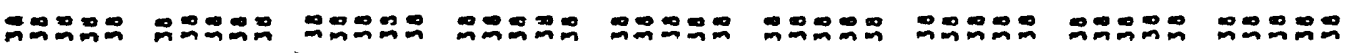

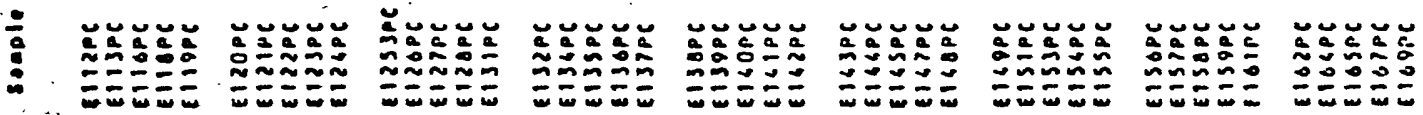




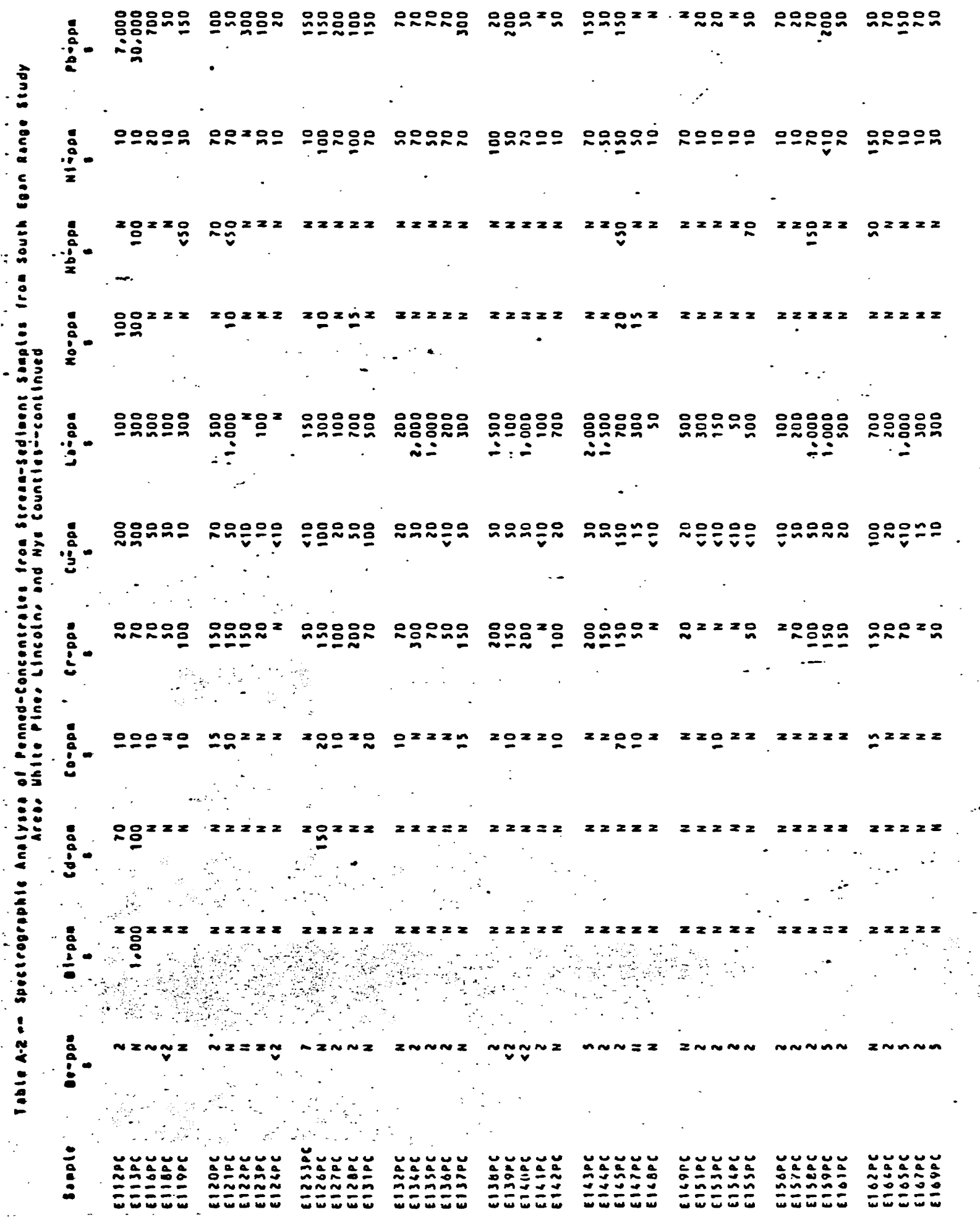




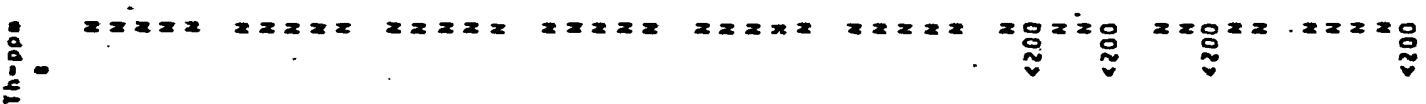

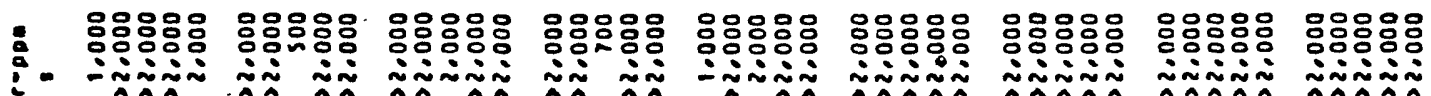

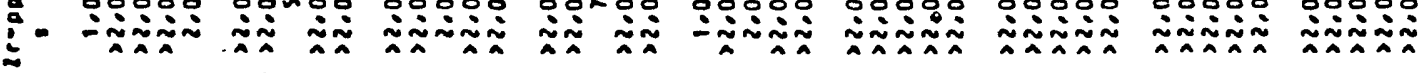

$:$
$: 0$

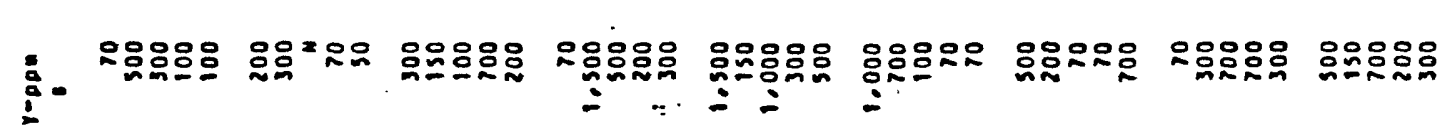

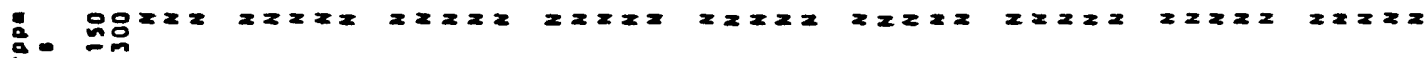

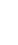

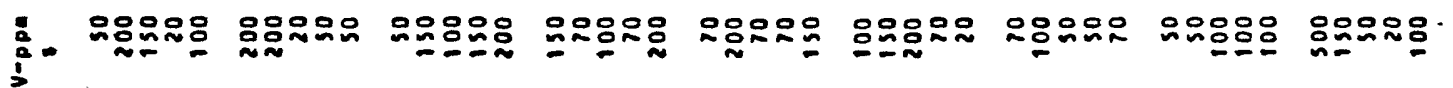

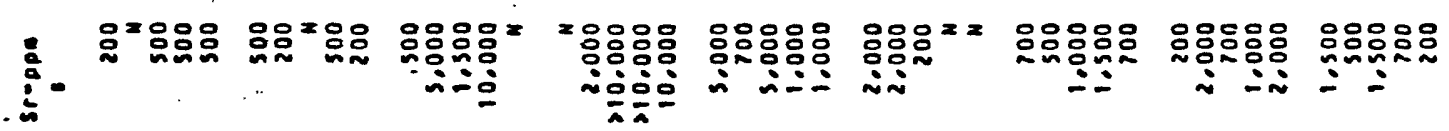

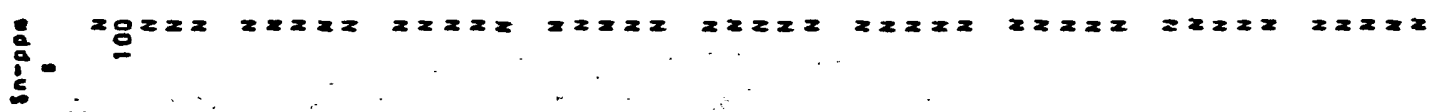

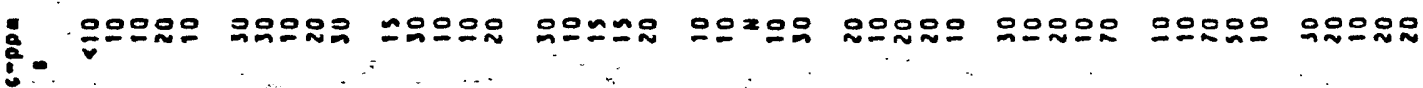

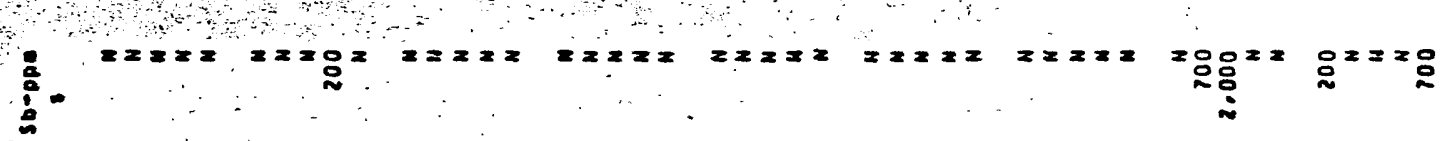

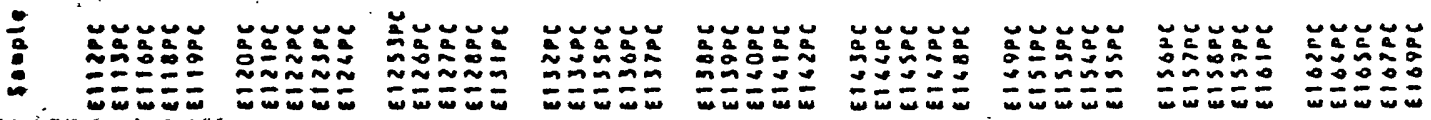




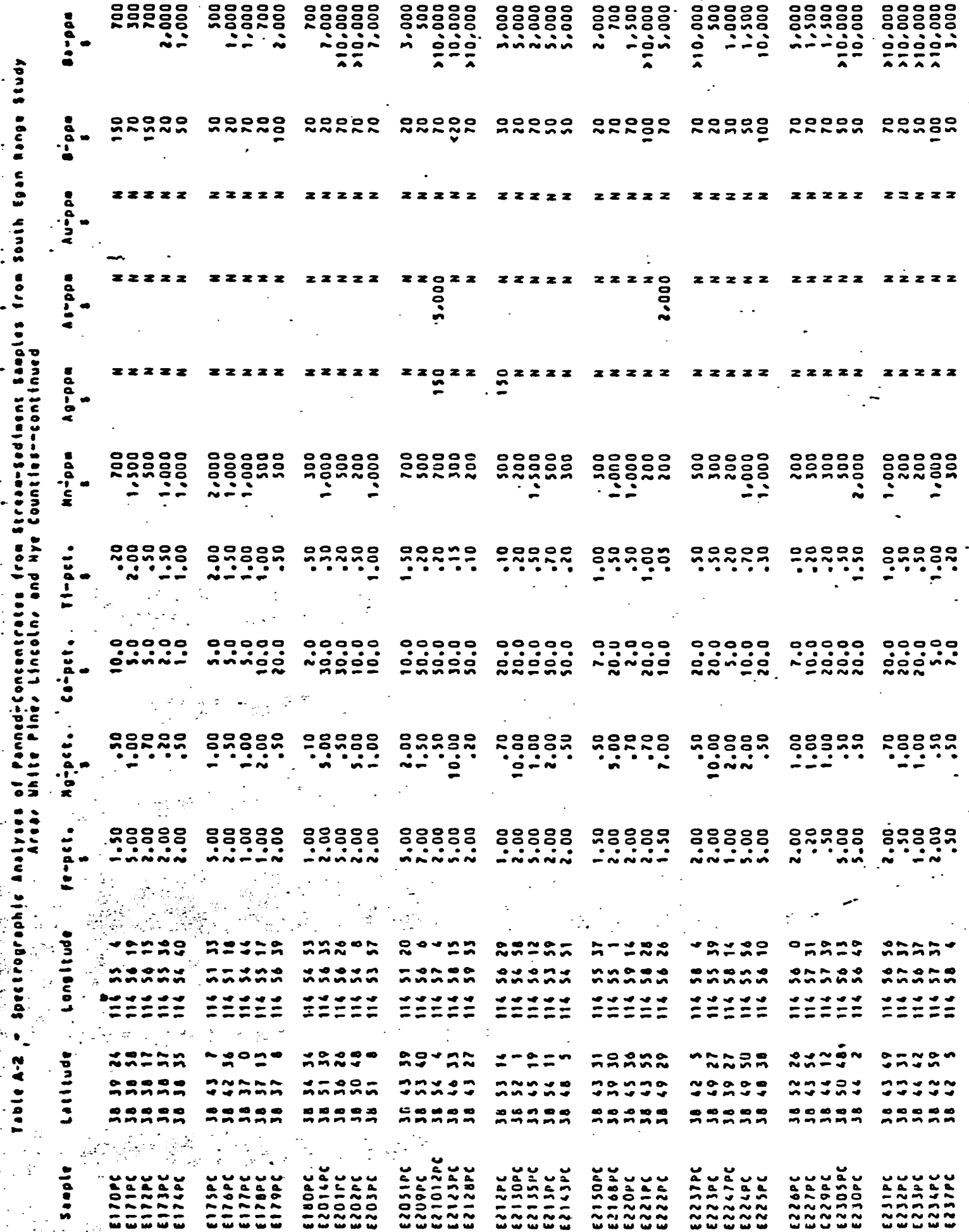




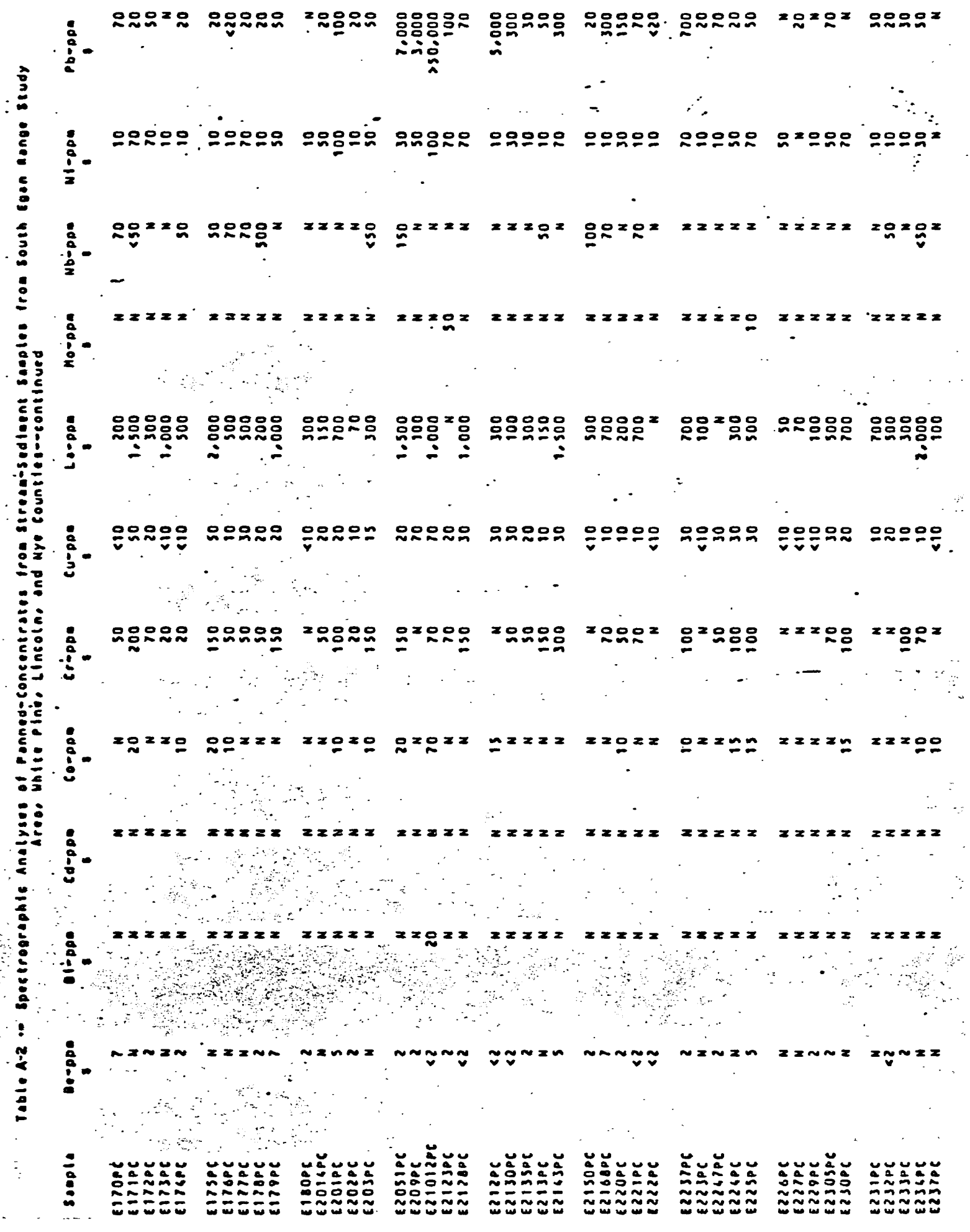




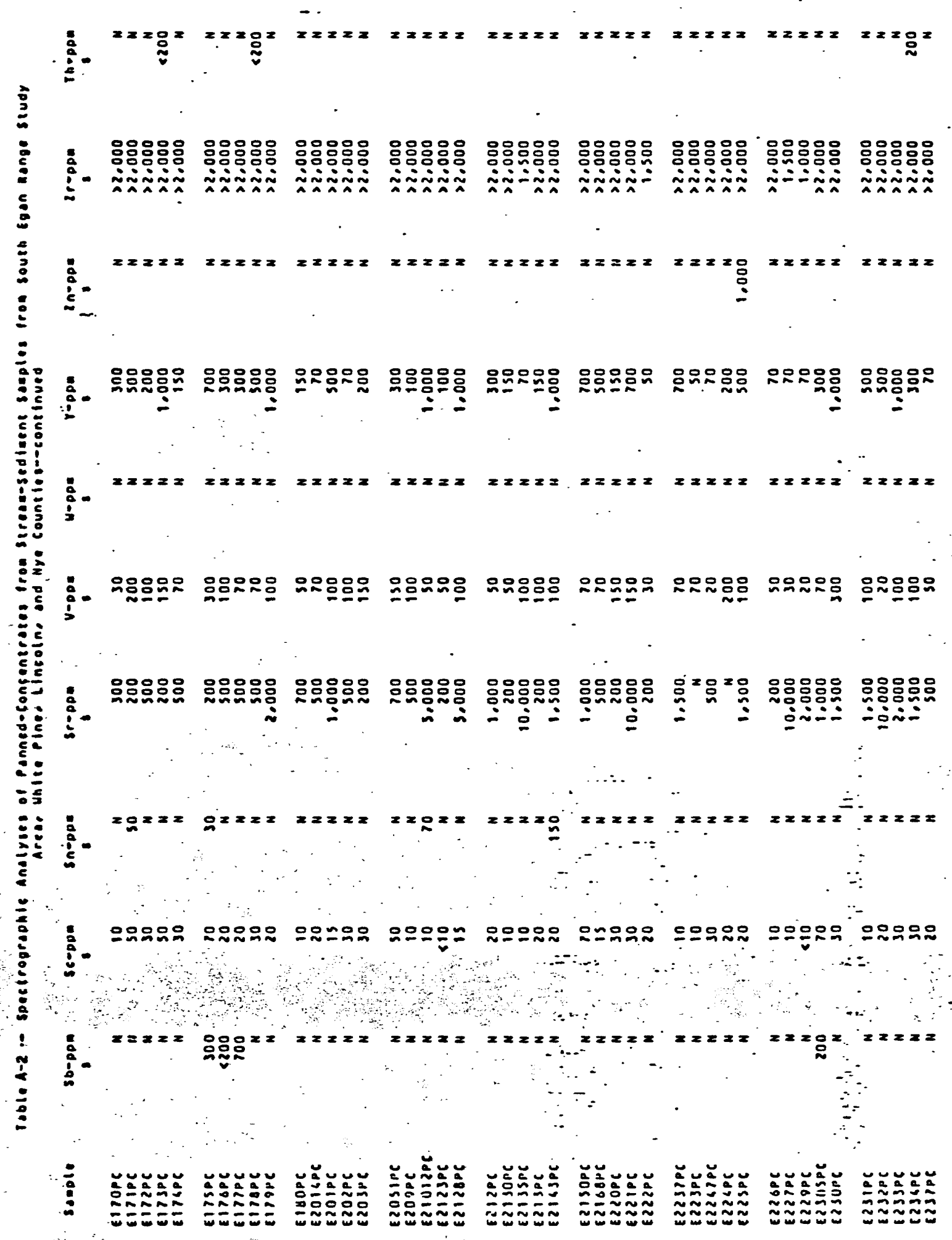




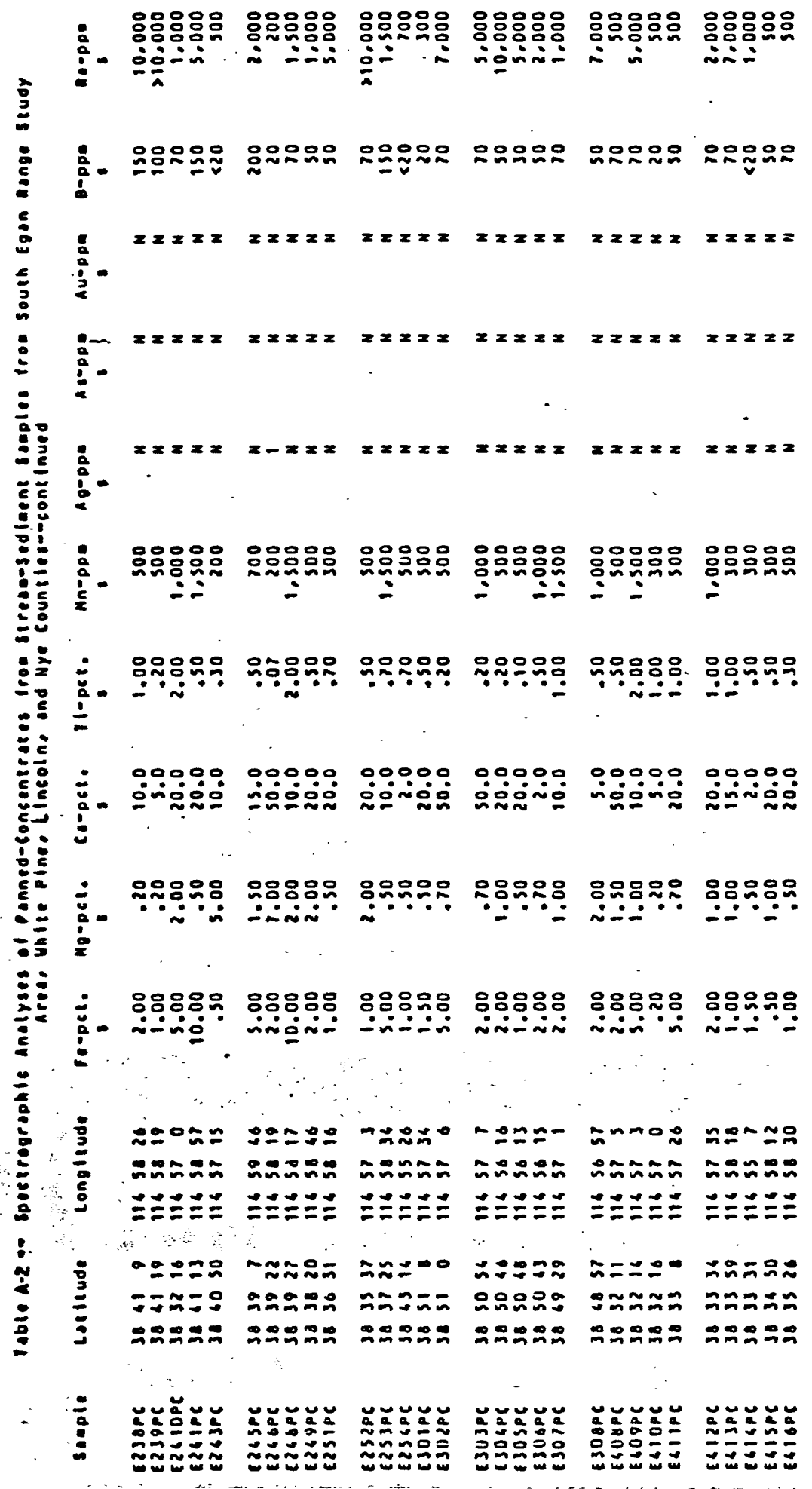




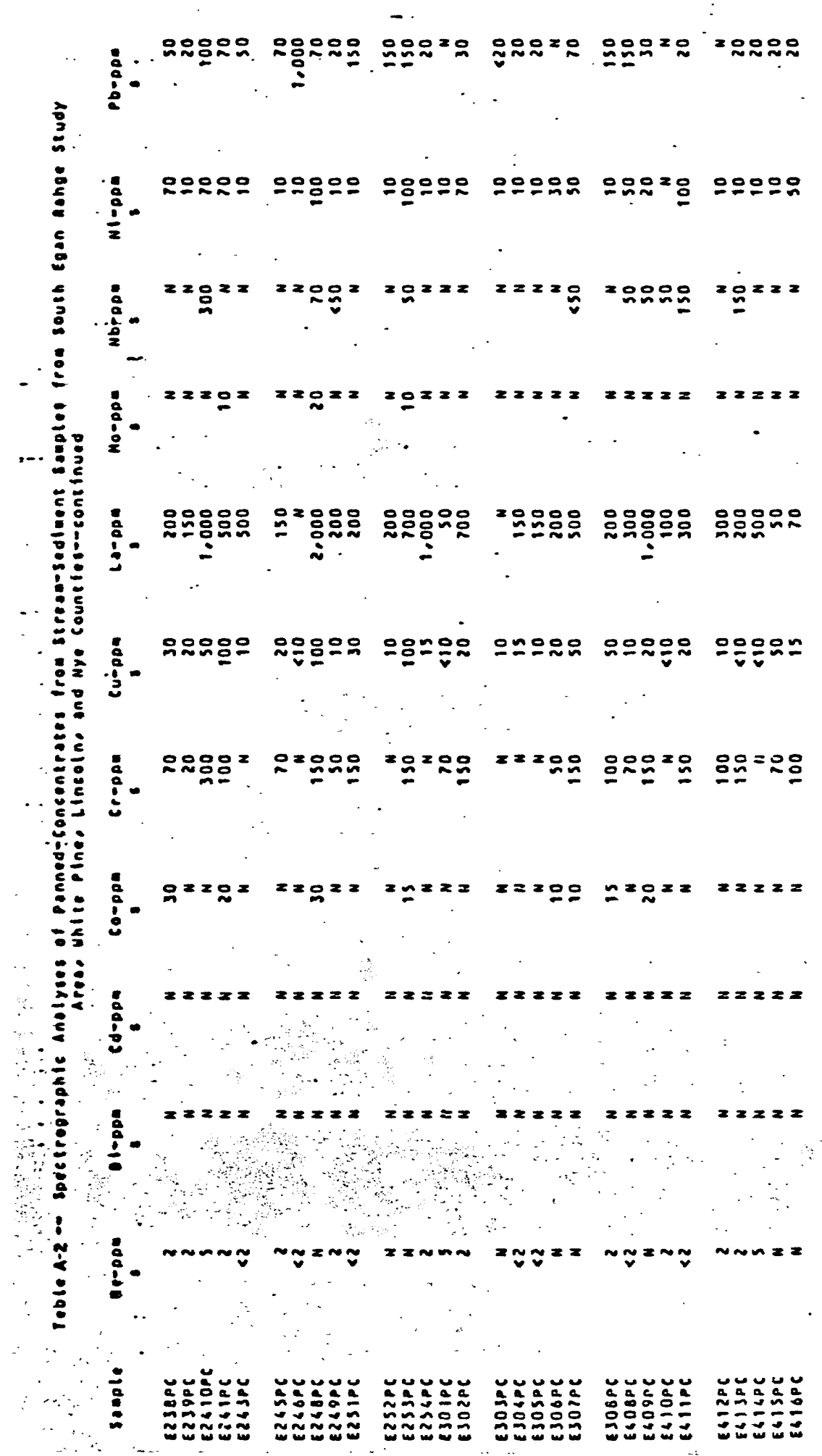




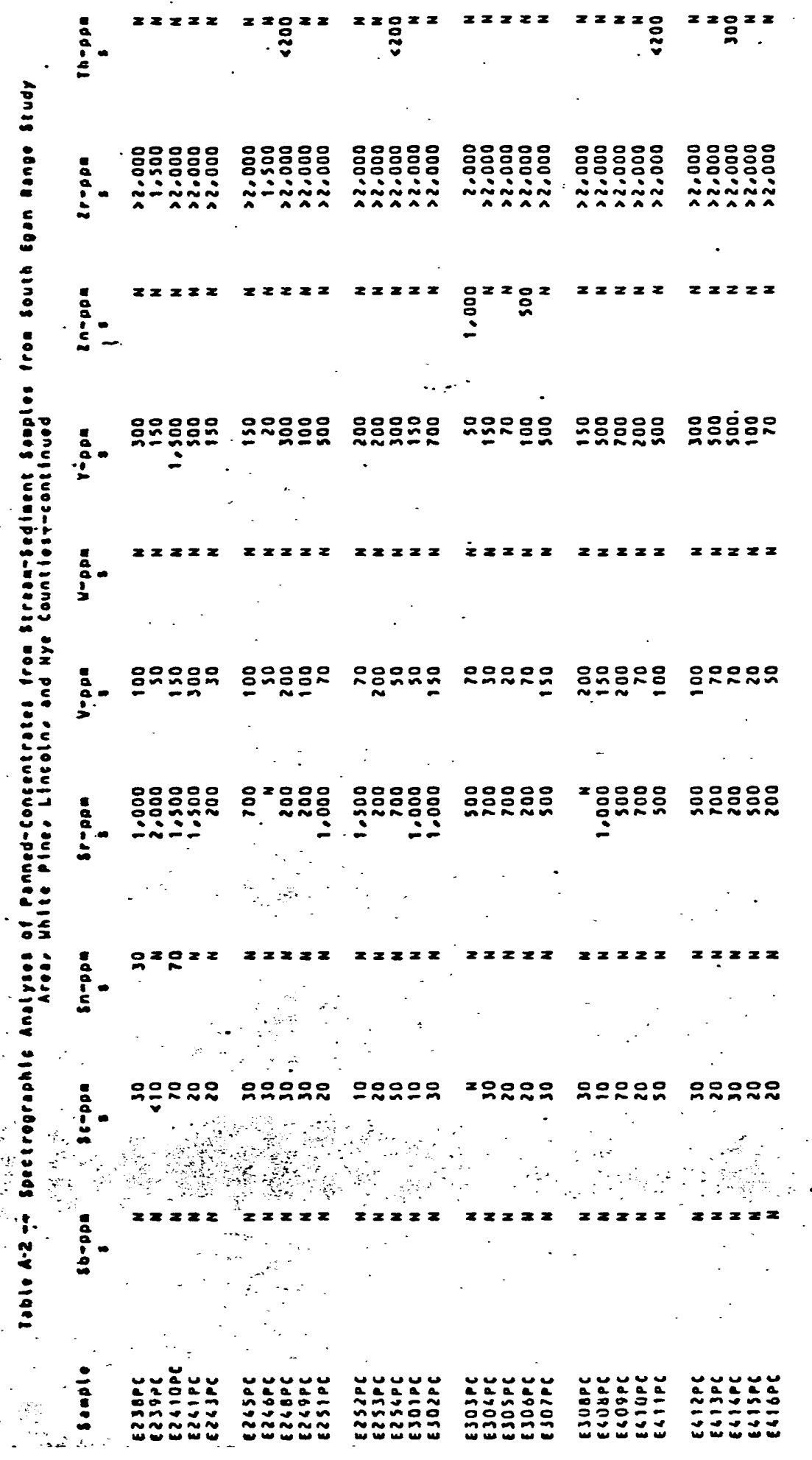




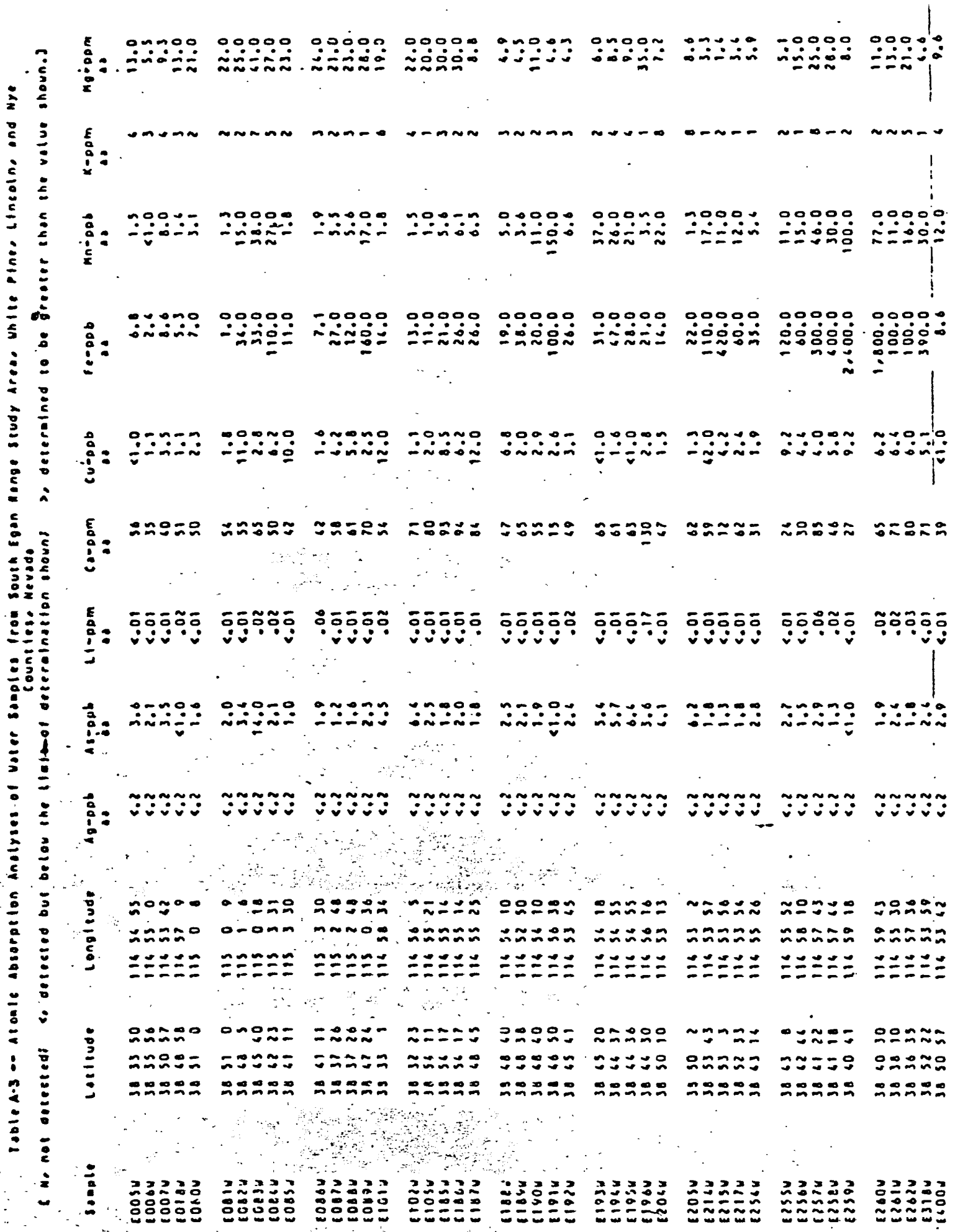




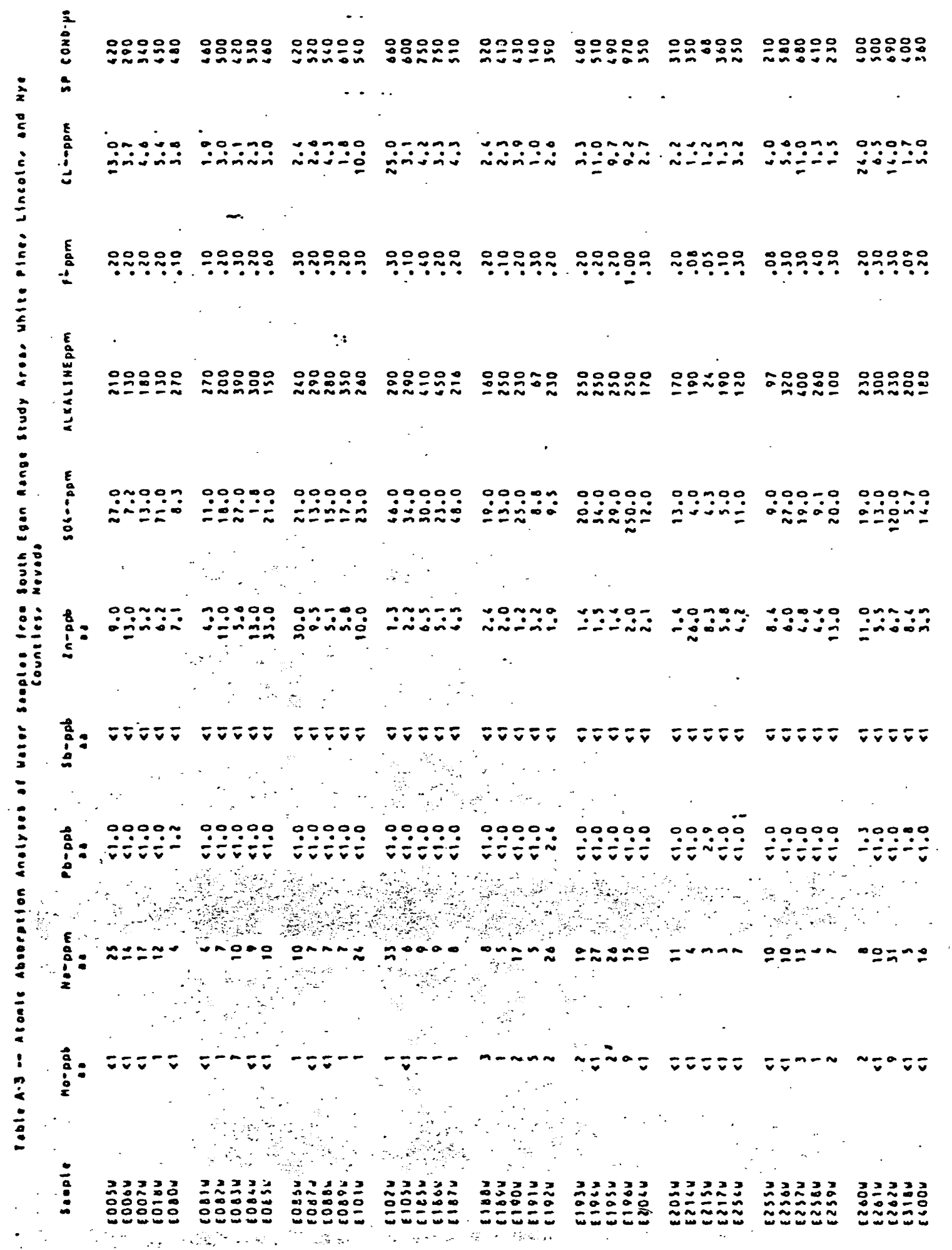




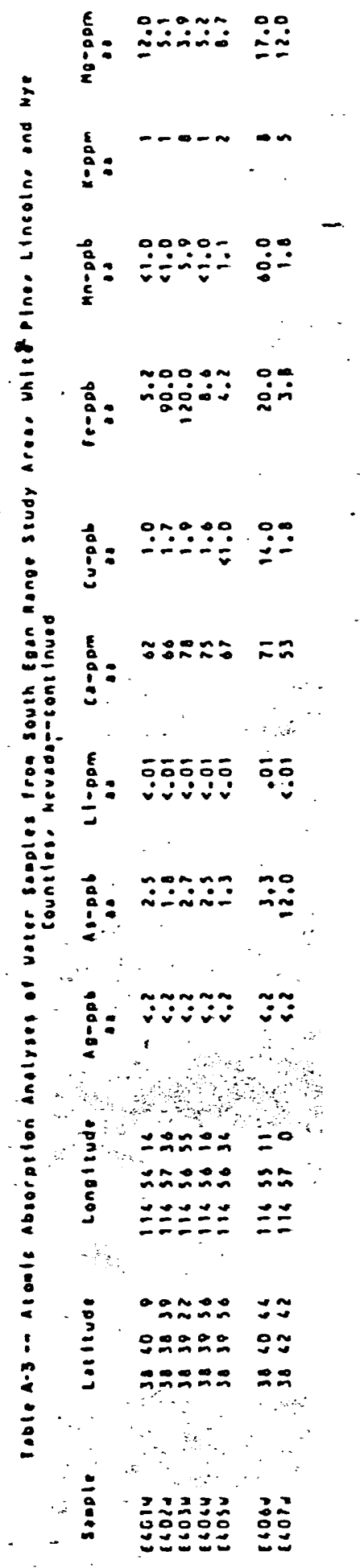




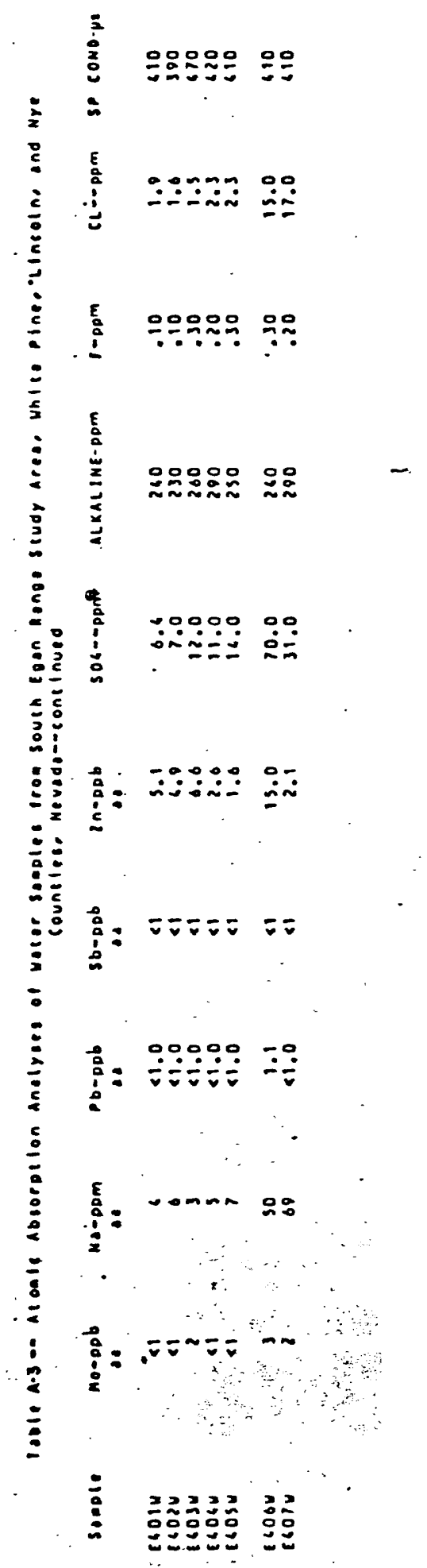




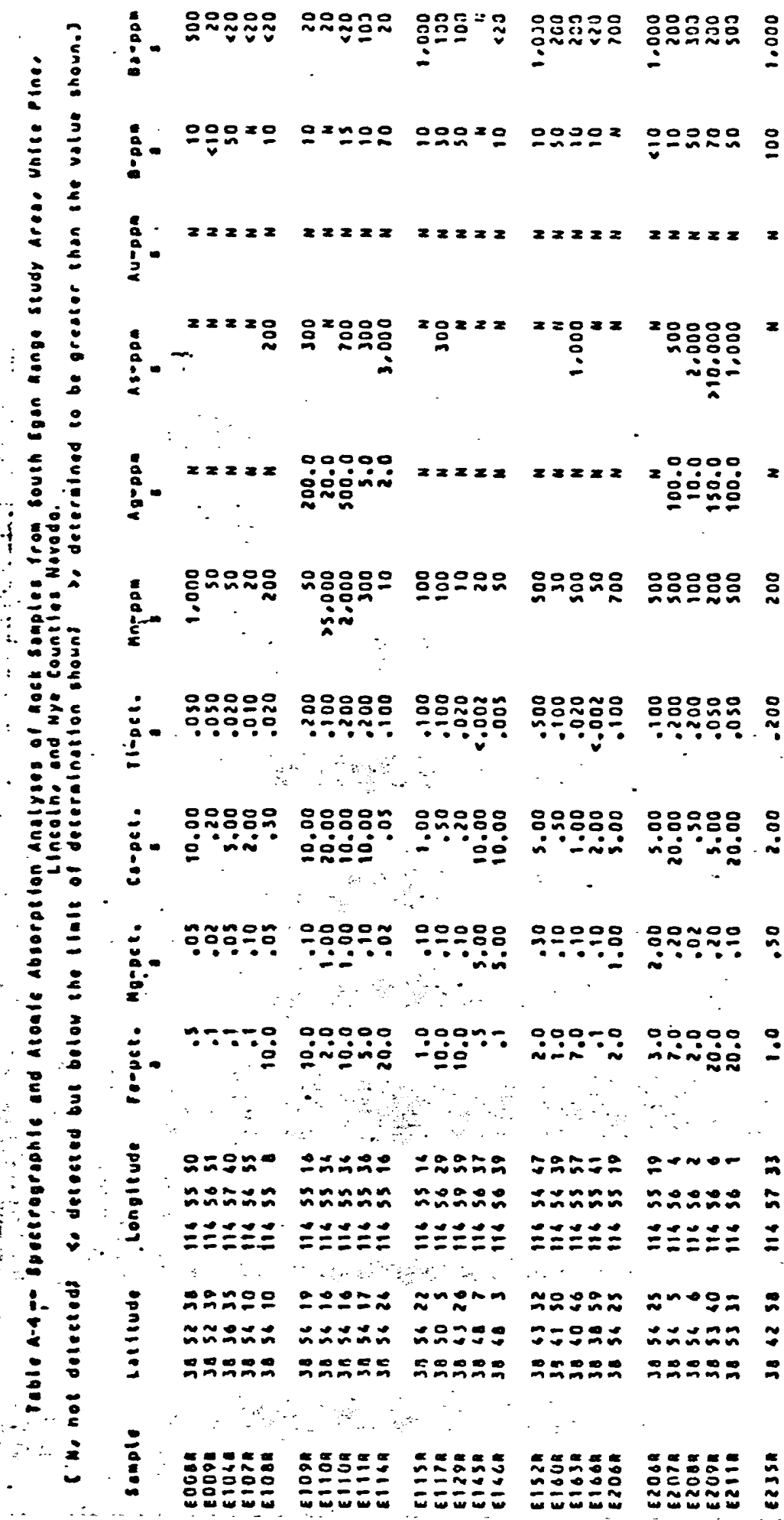




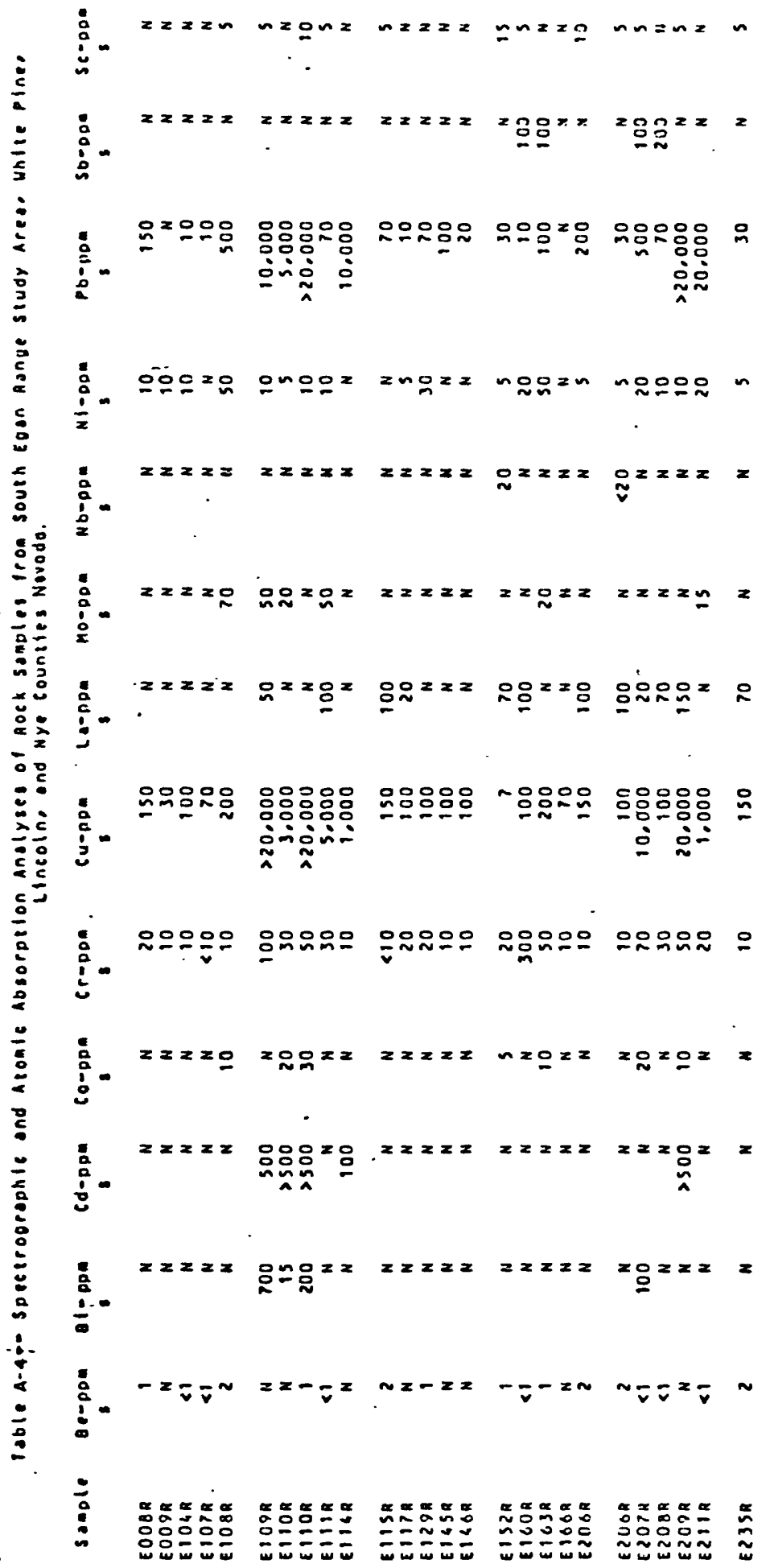




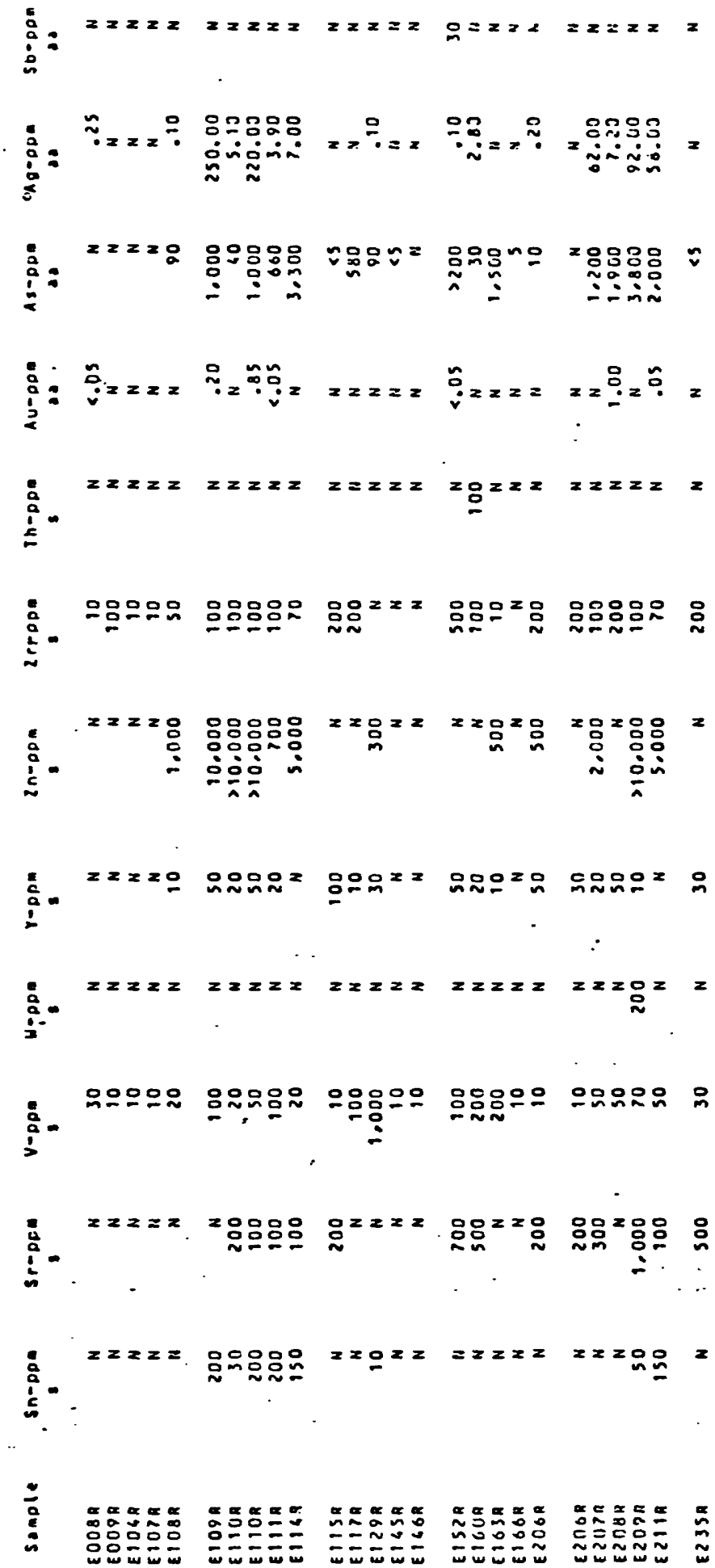

